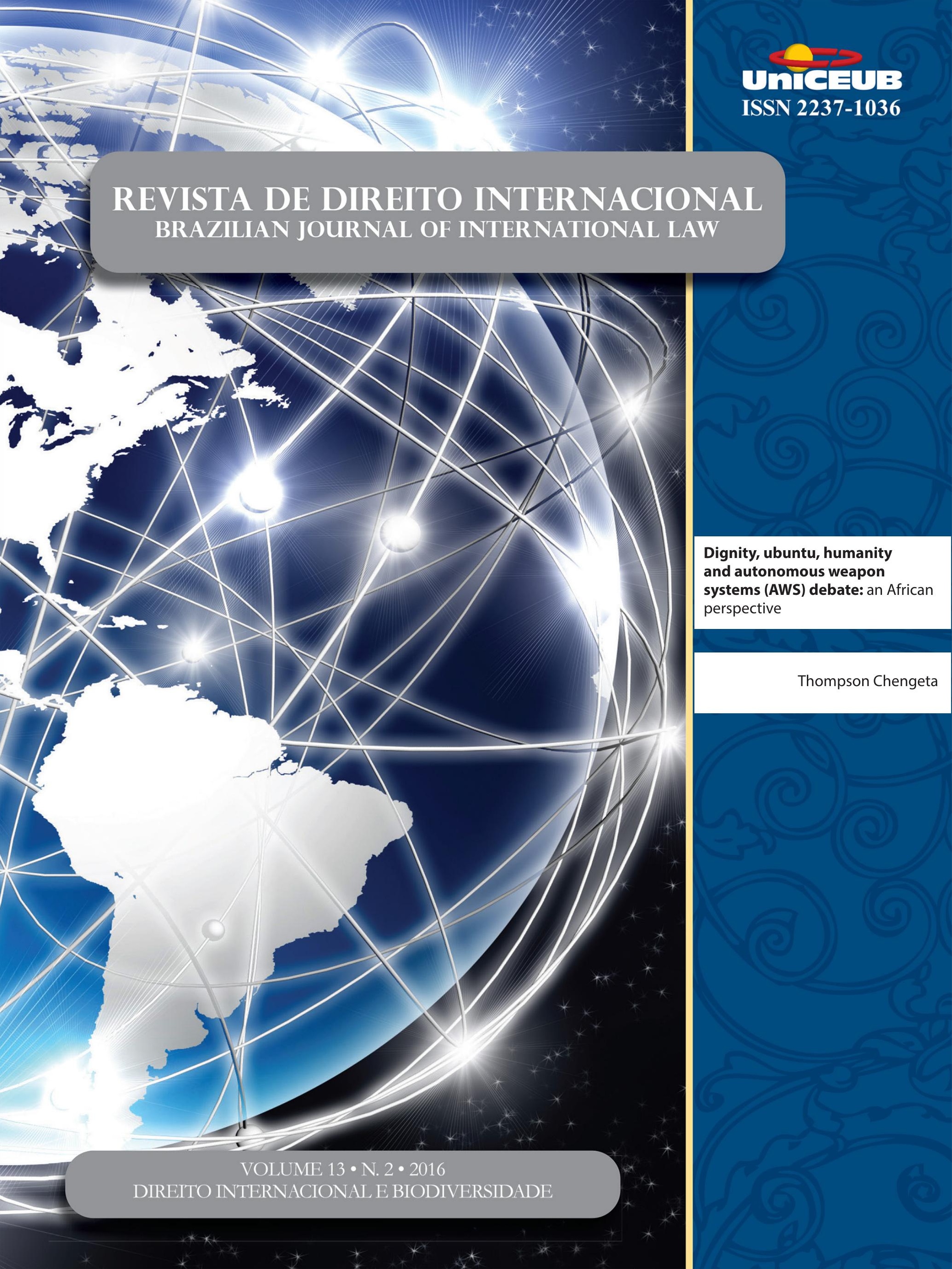




\section{Sumário}

CRÔNICAS DE DIREITO INTERNACIONAL PRIVADO 3 Gustavo Ferreira Ribeiro, Inez Lopes Matos Carneiro de Farias, Nadia de Araujo e Marcelo De Nardi

EDITORIAL 22

Márcia Dieguez Leuzinger e Solange Teles da Silva

IMPROVING THE EFFECTIVENESS OF LEGAL ARRANGEMENTS TO PROTECT BIODIVERSITY: AUSTRALIA AND BRAZIL .25

Paul Martin, Márcia Dieguez Leuzinger e Solange Teles da Silva

O RECONHECIMENTO DA DIGNIDADE DOS ELEMENTOS DA BIODIVERSIDADE COM BASE NO DIÁLOGO ENTRE O DIREITO INTERNACIONAL E O ORDENAMENTO JURÍDICO BRASILEIRO

Augusto César Leite de Resende

O REGIME INTERNACIONAL DO CLIMA E A PROTEÇÃO AOS “REFUgIADOS CLIMÁTICOS”: QUAIS DESAFIOS DA COP 21?

Ana Carolina Barbosa Pereira Matos e Tarin Cristino Frota Mont'Alverne

A anÁlise do MECANismo REdD+ COM Vistas À MitigaÇÃo dos EFEITOS DAS MUdANÇAS CLIMÁTICAS E À PROTEÇÃO DA DIVERSIDADE BIOLÓGICA FLORESTAL

Diogo Andreola Serraglio e Heline Sivini Ferreira

ECOLABELS DE EFICIÊNCIA ENERGÉtiCA E SUA CONSISTÊNCIA COM A DISCIPLINA DOS PPM's E PROVISÕES dOs Acordos GATT E TBT.

Cristiane Derani e Arthur Rodrigues Dalmarco

ANÁLISIS DEL ORDENAMIENTO JURÍDICO INTERNACIONAL SOBRE PROTECCIÓN DE LOS RECURSOS GENÉTICOS: DESAFIOS Y PERSPECTIVAS EN URUGUAY A PARTIR DE LA IMPLEMENTACIÓN DEL PROTOCOLO DE NAgOYA 115

Alina Celi 
LE RÉGIME INTERNATIONAL DE L'ACCÈS AUX RESSOURCES GÉNÉTIQUES AU PRISME DE L'ENTRÉE

en VIgUeUr du Protocole de NAgoya .............................................................. 131

Rodolpho Zahluth Bastos, Otávio Canto, Karine Galy e Isabelle Vestris

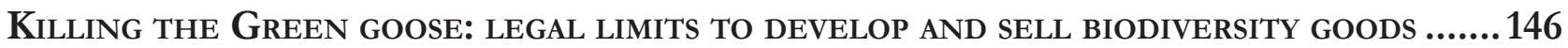
José Augusto Fontoura Costa e Liziane Paixão Silva Oliveira

VÍNCULO SUBSTANCIAL E AS BANDEIRAS DE CONVENIÊNCIA: CONSEQUÊNCIAS AMBIENTAIS DECORRENTES DOS NAVIOS COM REGISTROS ABERTOS ....................................................... 160

Marcos Edmar Ramos Alvares da Silva e André de Paiva Toledo

ANÁLISE DE CONTRATOS PÚblicos SOCIOAMBIENTAIS NO CENÁRIO PORTUGUÊS DE CRISE ECONÔ-

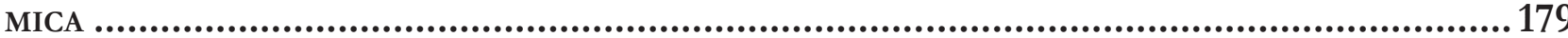

Alice Rocha da Silva e Matheus Passos Silva

A ORganizaÇão do TRATAdo DE COOPERAÇão AMAZÔNICA: UMA ANÁLISE CRÍTICA dAS RAZÕES POR TRÁS DA SUA CRIAÇÃO E EVOLUÇÃO

Paulo Henrique Faria Nunes

O uso de EXPERTS EM Controvérsias ambientais Perante a CorTe InTERnacional de JusTIÇA ........................................................................................................245

Lucas Carlos Lima

Os VIESES dA BIODIVERSIDAdE APRESENTAdos PELO CASO do PARQUE EÓlico DE BALd HiLls ......261 Natália Zampieri e Mariana Cabral

Mining CBD 275

Claire Lajaunie e Pierre Mazzega

Biotecnologia moderna, direito e o pensamento Abissal

Reichardt, F.V., Garavello, M. E. P. E., Molina, S.M.G. e Ballester, M. V. R.

Community Core Values como parâmetro de efetivação dos Princípios da Precaução e da Participação Popular em instrumentos de controle de projeto atividade de alta COMPLEXIDADE AMBIENTAL................................................................................... 314

Michelle Lucas Cardoso Balbino 
Discussões BIOTECNOLÓgICAS QUANTO AOS ORGANISMOS GENETICAMENTE MODIFICADOS NO ÂMBito da OMC: do contencioso ao acordo de vontades entre Argentina e União EuroPEIA

Gustavo Paschoal Oliveira

O Trans-Pacific Partnership Agreement e seus potenciais impactos para a regulação

DA BIODIVERSIDADE NO ÂMBITO TRANSNACIONAL..........................................................375

Mariana Yante Barrêto Pereira

AS ÁREAS PROTEGIDAS TRANSFRONTEIRIÇAS: REFLEXÕES CRÍTICAS ACERCA DE UM USO GEOPOLÍTICO DO DIREITO DA BIODIVERSIDADE.

Rabah Belaidi

O Que o caso Estados Unidos vs. Texas nos dirá sobre o direito de IMigração nos EsTADOS UNIDOS? 409

Danielle Anne Pamplona

Clóvis Beviláqua e a justiça internacional: entre o sim E o Não a Rui Barbosa.... .422 Paulo Emílio Vauthier Borges de Macedo

Possibilidade de delegação de atribuição para a Celebração de Tratados pela RepúbliCa Federativa do Brasil: análise do artigo 84, VIII c/c Parágrafo único da ConstituiÇão FEDERAL

Luciano Monti Favaro e Héctor Valverde Santana

Dignity, ubuntu, HUMANiTY AND AUTONOMOUS WEAPON SYSTEMS (AWS) DEBATE: AN AfRiCAN PERSPECTIVE 460

Thompson Chengeta

DiREITO INTERNACIONAL PRIVADO E O DIREITO TRANSNACIONAL: ENTRE A UNIFICAÇÃO E A ANARQUIA .503

André De Carvalho Ramos

A ilusória ausênCia do termo DépeÇage na JURisprudênCia brasileira de contratos INTERNACIONAIS

Gustavo Ferreira Ribeiro 
O EFEITO DIRETO DAS DIRETIVAS E OS DIREITOS FUNDAMENTAIS........................................535 Lucas Fonseca e Melo e José Levi Mello do Amaral Júnior

DA APLICABILIDADE DO BULK FACTORING AOS GRUPOS DE SOCIEDADES 565 Daniel Amin Ferraz e Leonardo Arêba Pinto

A Questão hermenêutica no direito das GENTES ................................................580 Inocêncio Mártires Coelho 


\title{
Dignity, ubuntu, humanity and autonomous weapon systems (AWS) debate: an African perspective
}

\author{
Dignidade, ubuntu, humanidade e o debate \\ sobre o sistema de armas autônomas: uma \\ perspectiva africana
}

Thompson Chengeta**

\begin{abstract}
In this paper, I discuss the relevance of the African notion of 'ubuntu' or humanity to the on-going AWS debate. After tracing the notion of ubuntu back to the pre-colonial time in Zimbabwe and how it developed into a political and humanist philosophy, I discuss its relevance in international law by reference to the impact of its equivalent notion of humanity to international human rights, humanitarian and criminal law. I also note that scholars who argue for the exclusion of the notion of humanity from the AWS debate base the argument either on the idea that the notion is inadequately defined or that humanity as a notion is so vague to the extent that relying on it will have disastrous results. In response to this argument, I seek to define the term humanity and linking it to human dignity in a bid to show that the term is capable of meaning. After defining what ubuntu or humanity means as shaped by human dignity, I come to the conclusion that giving robots the power to decide who lives or dies is inconsistent with ubuntu and an affront to human dignity. I also emphasise that African states should more fully participate in the on-going debate on AWS and share their experience with the notion of ubuntu with the rest of the world.
\end{abstract}

Keywords: Autonomous Weapon Systems. Killer robots. Dignity. Ubuntu. Humanity. Martens Clause.

\section{THE RELEVANCE OF THE NOTION OF UBUNTU/HUMANITY TO THE autonomous weapon systems debate: an African perspective.}

A person is a person through other people... Humanity is not embedded in my person solely as an individual; my humanity is co-substantively bestowed upon the other and me. Humanity is a quality we owe to each other. We create each other and need to sustain this otherness creation. And if we belong to each other, we participate in our creations: we are because you are, and since you are, definitely I am. The ' $\mathrm{I}$ am' is not a rigid subject, but a dynamic self-constitution dependent on this otherness creation of relation and distance. ${ }^{1}$

1 ONYEBUCHI, M. Eze. Community of Life: ecological theology in african perspective, 


\section{INTRODUCTION}

The development of unmanned systems that are remotely controlled and those with increased autonomy in their critical functions has been a worry to the international community for more than a decade now. The idea to develop autonomous weapon systems with increased autonomy in their critical functions (AWS) - machines that once activated are able to make the decision to kill humans without further human intervention - has sparked heated debates across the globe. The old adage, 'technology is a double-edged sword' ${ }^{2}$ has never, in the history of weapon development, been more pertinent than it is with AWS. On one hand, AWS clearly promise a potential to save lives - to make a change to the unacceptable current state of affairs in armed conflict and elsewhere - where force is used. At the same time, AWS pose potential threats to the right to life, dignity and other important rights. With the technology still in the preliminaries of development and yet to be deployed, it is as difficult to ascertain whether AWS are legal or illegal weapons as it is to brand their deployment ethical or unethical, moral or immoral when they become available. It is these uncertainties that have left scholars, organisations, states and the international community at large divided on how to respond to AWS.

In this paper, I seek to discuss the relevance of the African notion of 'ubuntu' or humanity to the AWS debate. Ubuntu as an ideology and political philosophy has informed many African governments' policies especially those that relate to human rights. I refer to the discussion on AWS from a humanist perspective as an African perspective on the technology generally because humanity - which is the equivalent of Ubuntu - on the African continent is not only a strong notion on the continent but it has served to shape many African communities and African government policies. This, of course, is not to say that the humanistic approach is exclusive to the African continent.

2008.

2 We have to realize that science is a double-edged sword. One edge of the sword can cut against poverty, illness, disease and give us more democracies, and democracies never war with other democracies, but the other side of the sword could give us nuclear proliferation, bio-germs and even forces of darkness.' See Michio Kaku available at: <http://www.brainyquote.com/quotes/keywords/ sword.html>. Accessed: 2 Aug. 2015.

\section{BACKGROUND}

Before discussing how the African notion of ubuntu or humanity can impact on the AWS debate, it is important to give a background to this issue. Distancing oneself from harm, albeit being the projector of it, has been and remains an inherent attribute of human beings. The desire to project harm while being insusceptible to it has largely shaped the development of weapons over the years. Currently, unmanned weapon systems are the epitome of that desire as states have been allocating huge budgets ${ }^{3}$ for the development of various sophisticated unmanned weapon systems and increasing their operational autonomy ${ }^{4}$.

An unmanned weapon system - which can be a ground or an aircraft system, remotely controlled or autonomous - is 'a powered physical system with no human operator aboard the principal platform' and is capable of carrying and delivering a lethal or non-lethal pay-load. Remotely controlled unmanned systems have no human physically on board although they are controlled by a human from a distance.

On the other hand, in the case of autonomous weapon systems, not only are humans not physically present but they are also psychologically absent as they are not in control of the critical functions of the system. Critical functions of an autonomous weapon system refer to the functions that relate to the selection, targeting and making the decision to kill a human being ${ }^{5}$.

The reason why sates are developing autonomous weapon systems is because these systems are not only technically faster, smarter and better than humans, but they offer a number of military advantages like force multiplication and tremendous capacity to do the dirty, dull, dangerous work thereby reducing risk to the lives of one's own soldiers. Further, since these robots will not act out of malice, they can potentially save the lives of civilians.

3 See: <http://military.discovery.com/weapons-technology >. Accessed: 29 Jan. 2015.

4 See United States Air Force 'UAS Flight Plan 2009-2047', 2009, 41. Available at: <http://www.scribd.com/doc/17312080/United-States-Air-Force-Unmanned-Aircraft-Systems-Flight-Plan20092047-Unclassified>. Accessed: 29 Jan. 2015.

5 See Report of the ICRC Expert Meeting on 'Autonomous weapon systems: technical, military, legal and humanitarian aspects', 26-28 March 2014, Geneva, available at: < http://www.icrc.org/eng/ assets/files/2014/expert-meeting-autonomous-weapons-icrc-report-2014-05-09.pdf > 
Notwithstanding these advantages, AWS also raise questions as to whether they can be able to comply with the law ${ }^{6}$. Further, scholars question the ethics and morality of deploying weapon systems that can make the decision to kill a human being without the assistance of a human? ${ }^{7}$.

\section{Status of the technology}

It is important to note, however, that at present AWS with full autonomy have not yet been deployed and do not exist. There are, however, advanced development of the technology. The US, the UK, Israel and North Korea possess robots that already function semi-autonomously ${ }^{8}$.

For many years, the idea of robots that have the ability to independently make decisions to kill without the help of humans has been restricted to the fictitious world of novels ${ }^{9}$ and movies ${ }^{10}$. Humans' wariness about lethal robots that can autonomously decide to kill is often depicted in story lines that involve terrifying situations where robots massacre humans or robots initially designed to assist humans end up turning against them.

6 See KRISHNAN, A. Killer robots: legality and ethicality of autonomous weapons. Ashgate Publishing, 2013; MARCHANT, G. et al. International governance of autonomous military robots. Columbia Science and Technology Law Review, v. 280, n. 12, 2011.

7 See ARKIN, R. Governing lethal behaviour: embedding ethics in a hybrid deliberative/reactive robot architecture. Technical Report GIT-GVU, 2011. FINN, A.; SCHEDING, S. Developments and challenges for autonomous unmanned vebicles: a compendium. Springer Science \& Business Media, 2010.; LIN P. et. al. Robot ethics: the ethical and social implications of robotics. MIT Press, 2011.; SINGER, P. W. Wired for war: the robotics revolution and conflict in the $21 \mathrm{st}$ century. Penguin, 2009.; SPRINGER, P. J. Military robots and drones. ABC-CLIO, 2013.; ASARO, P. How just could a robot war be? In: BREY P. et. al. (Ed.). Current issues in computing and philosophy. IOS Press, 2008.; ANDERSON, K.; WAXMAN, M. Law and ethics for robot soldiers. American University WCL Research, v.32, iss. 18, 2012.; SHARKEY, N. The evitability of autonomous robot warfare. International Review of the Red Cross, 2012.

8 Semi-autonomous systems are defined as 'a weapon system that, once activated, is intended to only engage individual targets or specific target groups that have been selected by a human operator.'- US Department of Defense Autonomy in Weapon Systems. Directive 3000.09, 2012, 14 available at: <http://www.dtic.mil/whs/ directives/corres/pdf/300009p.pdf>. Accessed: 3 Jan. 2013.

9 See novels like I, Robot (1950), The Caves of Steel (1953), The Naked Sun (1955), The Robots of Dawn (1983) and Robots and Empire (1985).

10 See for example 'Star wars: a new hope', 'The Terminator', 'Robocop' and 'Forbidden Planet'.
Until in recent years, scholarly discussion on such kind of robots could not be taken seriously as many people believed and hoped that they would remain the art of fiction and never see the light of the day ${ }^{11}$. That hope is, however, fading away since autonomous weapon systems are looming on the horizon of the real world. As noted above, military semi-autonomous robots are already in the employ of some states.

Malfunctioning of military robots and some turning against their own users has already been experienced in the real world ${ }^{12}$. For example, in 2007, during a training session in South Africa, one of the robot cannons mysteriously started firing on its own, killing nine South African soldiers and wounding $14{ }^{13}$. In the Iraq war in 2008, ground kill-droids were reported to have 'turned on their fleshy masters almost at once [leading to the] rebellious machine warriors [being] retired from combat pending upgrades. ${ }^{14}$.

\section{The Response to AWS technology so far - an absence of African scholarship}

In April 2013, Human Rights Watch and other human rights $\mathrm{NGOs}^{15}$ came together to form the 'Campaign to stop Killer robots' $(\mathrm{CKR})^{16}-$ a non-governmental organisation whose mandate is to crusade 'for a pre-emptive and comprehensive ban on the development, production, and use of fully autonomous weapons, also known as lethal autonomous robots. ${ }^{37}$ Human Rights Watch has also published a number of reports outlining the concerns in the ever increasing au-

11 KRISHNAN, A. Killer robots: legality and ethicality of autonomous weapons. Ashgate Publishing, 2013.

12 WEINBERGER, S. Charity battles imaginary killing machines, 2008. Available at: <http://www.wired.com/2008/03/charity-will-ba/>.

13 SHACHTMAN, N. Robot cannon kills 9, wounds 14, 2007. Available at: <http://www.wired.com/dangerroom/2007/10/robotcannon-ki/ $>$.

14 PAGE, L. US war robots in Iraq 'turned guns' on fleshy comrades: killdroid rebellion thwarted this time, 2008. Available at: <http://www. theregister.co.uk/2008/04/11/us_war_robot_rebellion_iraq/ >.

15 Article 36, Association for Aid and Relief Japan, International Committee for Robot Arms Control, Mines Action Canada, Nobel Women's Initiative, IKV Pax Christi Pugwash Conferences on Science \& World Affairs, Women's International League for Peace and Freedom.

16 All the major activities of the CKR are available on their website, see: <http://www.stopkillerrobots.org $>$.

17 See: <http://www.stopkillerrobots.org/call-to-action/>. Accessed: 30 May 2013. 
tonomy in weapon systems ${ }^{18}$.

The call to ban AWS has been supported by the European Parliament (EP). The EP adopted Resolution 2014/2567(RSP) which in part calls for a ban on 'the development, production and use of fully autonomous weapons which enable strikes to be carried out without human intervention. ${ }^{19}$.

At the same time, there are other commentators who argue that there is no basis in terms of the law to ban AWS and, in fact, a ban may be prejudicial in light of the possible positive advantages that AWS may bring ${ }^{20}$. Ron Arkin, for example, argues that 'a ban ignores the moral imperative to use technology to reduce the persistent atrocities and mistakes that human war fighters make. ${ }^{21}$. To Arkin, a ban is, at the very least, premature ${ }^{22}$.

In May 2013, the United Nations Special Rapporteur on extrajudicial, summary or arbitrary executions, Christof Heyns, submitted a report on AWS to the Human Rights Council (HRC) wherein he noted the advantages and concerns on AWS. Heyns compiled his report after holding expert consultation meetings on AWS earlier in 2012 and 2013 with roboticists, military experts, philosophers and international lawyers ${ }^{23}$. In his 2013 report, Heyns called for an international moratorium on 'the testing, production, assembly, transfer, acquisition, deployment and use of AWS until such time as an internationally agreed upon framework for the future of AWS has been established. ${ }^{24}$.

Not only did Heyns' 2013 report on AWS introduce the subject matter in the HRC, but it sparked a serious

18 HUMAN Rights Watch. Losing Humanity: The case against killer robots. 2012. Available at: <http://www.hrw.org/reports/2012/11/19/losing-humanity-0>.

19 Resolution available at: http://www.europarl.europa.eu/sides/ getDoc.do?pubRef =- / /EP/ NONSGML+MOTION+P7-RC2014-0201+0+DOC+PDF+V0//EN. accessed 5 March 2014.

20 ANDERSON, K.; WAXMAN, M. Law and ethics for autonomous weapon systems: why a ban won't work and how the laws of war can. American University Washington College of Law Research Paper, v. 3, 2013.

21 ARKIN, R. C. Lethal autonomous systems and the plight of the non-combatant. Ethics and Armed Forces, v. 9, 2014.

22 ARKIN, R. C. Lethal autonomous systems and the plight of the non-combatant. Ethics and Armed Forces, v. 9, 2014.

23 The expert consultation meetings were held in South Africa, at the Institute for International and Comparative Law in Africa of University of Pretoria and at the European University Institute in Florence, Italy, organised by the New York University Law School.

24 See http://www.ohchr.org/Documents/HRBodies/HRCouncil/RegularSession/Session23/A-HRC-23-47_en.pdf. Accessed: 19 Mar. 2014. debate on the issue amongst states and has since become one of the basic references whenever and wherever the issue of AWS is discussed. Less than a month after Heyns' presentation in the Human Rights Council, on 17 June 2013; the United Kingdom's House of Commons tabled the issue of AWS ${ }^{25}$. As will be discussed below and largely in response to Heyns report, states parties to the Convention on Conventional Weapons took up the matter in late 2013 and held a meeting on lethal autonomous weapon systems in May 2014 and subsequently in April 2015.

The International Committee of the Red Cross (ICRC) has also seized the matter of AWS. From 26 to 28 March 2014, the ICRC held an expert meeting on autonomous weapon systems. The meeting was attended by 21 states and 13 independent experts amongst them jurists, ethicists, roboticists, and representatives of non-governmental organisations and the United Nations. The major aim of the meeting was 'to better understand the issues raised by autonomous weapon systems and to share perspectives among government representatives, independent experts and the ICRC.26 This meeting followed the ICRC earlier publication titled 'New technologies and warfare' which discusses 'new weapons, means and methods of warfare to help governments fulfil their obligation to ensure that the use of new weapons, means or methods of warfare comply with the rules of [international humanitarian law' ${ }^{27}$. The ICRC presented a report of the March meeting to the May 2014 CCW Meeting on Lethal Autonomous Weapon Systems ${ }^{28}$.

In November 2013, at the 2013 Convention on Conventional Weapons (CCW) Meeting of High Contracting Parties, a new mandate on lethal autonomous weapons systems (LAWS) was agreed on.

25 See http://www.publications.parliament.uk/pa/cm201314/ cmhansrd/cm130617/debtext/130617-0004.htm. Accessed: 23 Sept. 2013.

26 See: <http://www.icrc.org/eng/resources/documents/ report/05-13-autonomous-weapons-report.htm>. Accessed: 27 Jun. 2014.

27 ICRC. Humanitarian debate: law, policy and action: new technologies and warfare. International Review of the Red Cross, v. 886, n.94, 2012.; ICRC. A guide to the legal review of new weapons, means and methods of warfare: measures to implement article 36 of additional protocol I of 1977. International Review of the Red Cross, v. 88, n. 864, 2006.

28 See: <http://www.icrc.org/eng/resources/documents/ report/05-13-autonomous-weapons-report.htm>. Accessed 28 June 2014. 
According to the mandate;

\begin{abstract}
A Chairperson will convene in 2014 a four-day informal Meeting of Experts, from 13 to 16 May 2014, to discuss the questions related to emerging technologies in the area of lethal autonomous weapons systems, in the context of the objectives and purposes of the Convention. He will, under his own responsibility, submit a report to the 2014 Meeting of the High Contracting Parties to the Convention, objectively reflecting the discussions held ${ }^{29}$.
\end{abstract}

From 13 to 17 May 2014, the CCW held an expert meeting on lethal autonomous weapon systems which was chaired by Ambassador Jean-Hugues Simon-Michel of France. ${ }^{30}$ In the meeting, representatives of States parties to the CCW, non-governmental organisations, the European Union, United Nations Institute for Disarmament Research (UNIDIR), the United Nations Office of Disarmament Affairs (UNODA), International Committee of the Red Cross, Geneva Academy of International Humanitarian Law and Human Rights, Institute of International and Comparative Law in Africa, International Institute of Humanitarian Law, International Studies Association (ISA), Nanzan University Japan, Graduate Institute of International Development Studies (IHEID), Peace Research Institute Frankfurt (PRIF), University of Strasbourg, New York University, University of St. Gallen and independent experts like jurists, ethicists and roboticists discussed the 'technical issues; ethics and sociological issues; international humanitarian law (IHL); other areas of international law; and operational and military aspects' of lethal autonomous weapon systems ${ }^{31}$.

At the end of the CCW meeting, delegations highlighted that although the meeting had to some extent formed common understandings in certain aspects, some of the important questions and concerns noted above still remained unanswered. It was therefore agreed that the issue must be taken further during the next meeting of High Contracting Parties to the CCW in 2014 and

29 See: <http://www.unog.ch/80256EE600585943/\%28httpPag es\%29/6CE049BE22EC75A2C1257C8D00513E26?OpenDocume nt $>$. Accessed 27 June 2014.

30 See: <http://www.unog.ch/80256EE600585943/\%28httpPag es\%29/6CE049BE22EC75A2C1257C8D00513E26?OpenDocume nt>. Accessed 27 June 2014.

31 See Report of the 2014 informal Meeting of Experts on Lethal Autonomous Weapons Systems (LAWS), Available at: <http://www.unog.ch/80256EDD006B8954/\%28httpAssets\% 29/350D9ABED1AFA515C1257CF30047A8C7/\$file/Report_ AdvancedVersion_10June.pdf>. Accessed: 27 Jun. 2014. the debate must be continued ${ }^{32}$. The material containing the positions of member states and the presentations of experts is available on the CCW website ${ }^{33}$. A follow up meeting was recently held in April 2015 wherein various experts, organisations and states made their presentations on the issue of AWS ${ }^{34}$.

What is striking is that in most of the UN meetings on AWS, a few African states participated. This is where I am arguing that participating of African states in some of these debates is fundamental. Certain African values, notions and perceptions need also to be filtered in whenever important issues are discussed and policies formulated. As will be argued below, some of these weapons and the regulation thereof end up affecting some African countries even if they did not participate in their development or formulation.

\section{African Ubuntuism/humanism and AWS}

Before articulating how the notion of ubuntu is impacted by the development and deployment of autonomous systems, it is important to briefly articulate what the term ubuntu means and also trace its origins. It should be stressed however, that the ultimate goal is to measure whether AWS without meaningful human control are in line with the African notion of Ubuntu or otherwise humanity. Expectedly, the discussion will not only focus on Ubuntu and humanity but also on the right to dignity which is an integral part of humanity.

In Africa, the roots of ubuntu as an ideology and a political philosophy can be traced back to Zimbabwe's independence struggle against colonial domination. Ubuntu is a Nguni term which is equivalent to unbu or bunbu, which are words from the Shona language that is spoken by the majority of people in Zimbabwe. In 1980, just as Zimbabwe was gaining its independence, a Zimbabwean author, JWT Samkange, published the

32 See Report of the 2014 informal Meeting of Experts on Lethal Autonomous Weapons Systems (LAWS), Available at <http://www.unog.ch/80256EDD006B8954/\%28httpAssets\% 29/350D9ABED1AFA515C1257CF30047A8C7/\$file/Report_ AdvancedVersion_10June.pdf $>$. Accessed 27 Jun. 2014.

33 See: <http://bit.ly/1jSlCro>. Accessed: 27 Jun. 2014.

34 See: 2015 Expert Meeting on LAWs Available at: <http:// www.unog.ch/80256EE600585943/\%28httpPages\%29/6CE049B E22EC75A2C1257C8D00513E26?OpenDocument>. Accessed: 20 May 2015. 
first literature articulating ubuntu as a philosophical concept upon which governance must be based ${ }^{35}$.

Literally understood, the word ubuntu is a combination of the root $-n t u$ which means a person or human being with the prefix ubu- thereby forming abstract nouns $^{36}$. In this sense, the term ubuntu is the equivalent of 'humanity'. During the armed struggle against colonial domination in Zimbabwe, the term was understood to mean such things as 'human nature, humanness, humanity; virtue, goodness, kindness', virtues that were associated with those who supported the struggle of the black majority against white minority domination ${ }^{37}$. Then, especially in the 1970s, the term 'ubuntu' denoted a special kind of 'African humanism' the kind only found in blacks but completely lacking in whites. Even in present day Zimbabwe, sometimes the term 'munhu' is used exclusively to refer to a black person.

However, by 1980, perceptions of what 'ubuntu' or 'hunhu' means gained a wide interpretation to include every human being. For example, Samkange espoused three factors that underlie Hunhuism or Ubuntuism:

\footnotetext{
'To be human is to affirm one's humanity by recognizing the humanity of others and, on that basis, establish respectful human relations with them.'

'If and when one is faced with a decisive choice between wealth and the preservation of the life of another human being, then one should opt for the preservation of life'.

'The king owes his status, including all the powers associated with it, to the will of the people under $\operatorname{him}^{38}$
}

In the modern day Zimbabwe, virtues go into what constitutes 'unhu', these include but not limited to the following: respecting others, sharing provisions with others, dressing properly, respecting elders ${ }^{39}$. Further-

35 See SAMKANGE, J. W. T. Hunhuism or Ubuntuism: a Zimbabwe indigenous political philosophy, 1980.

36 See also Zulu noun classes on Wiktionary.

37 See SAMKANGE, J. W. T. Hunhuism or Ubuntuism: a Zimbabwe indigenous political philosophy, 1980.

38 See SAMKANGE, J. W. T. Hunbuism or Ubuntuism: a Zimbabwe indigenous political philosophy, 1980.

39 As far as sharing provisions is concerned, Nelson Mandela had this to say about Ubuntu: 'A traveller through a country would stop at a village and he didn't have to ask for food or for water. Once he stops, the people give him food and attend him. That is one aspect of Ubuntu, but it will have various aspects. Ubuntu does not mean that people should not enrich themselves. The question therefore is: Are you going to do so in order to enable the community around you to be able to improve?' more, in a cutting edge example against individualism, elderly people must be called by their surnames instead of their first names. In this sense, individualism is banished and replaced by a representative role, in other words, an individual stands for his relatives or those who share the same name with him $^{40}$. In such scenarios, it is observed that the individual identity is replaced with the larger societal identity within the individual' where 'families are portrayed or reflected in the individual and this phenomenon is extended to villages, districts, provinces and regions being portrayed in the individual. ${ }^{31}$. The effect of this setup is that individuals are constantly forced to be in good behaviour since not only their name will be in jeopardy but the name of their family, village or whatever the case may be. It is in the same sense that the behaviour of daughters in law - known as varoora - is considered to be reflective of her family or the people who raised her. Ubuntu or 'hunhu' is the sacrosanct of togetherness, a notion under which there are no orphans since children belong to the whole village or community.

The notion of Ubuntu did not remain in Zimbabwe; it spilt across borders and spread across the African continent. For example, in South Africa, ubuntu was a guiding star during the transition from apartheid to majority rule. The South African legislature saw it fit to include the term in the Interim Constitution of South Africa where it categorically stated that 'there is a need for understanding but not for vengeance, a need for reparation but not for retaliation, a need for ubuntu but not for victimization. ${ }^{42}$.

In South Africa and during Nelson Mandela's presidency, the notion of 'ubuntu' was popularised in English literature by Desmond Tutu who saw the ubuntu as 'the essence of being human' and 'the fact that you can't exist as a human being in isolation. ${ }^{43}$.

The South African judiciary has also invoked the notion of ubuntu in the judgments of South African courts. For example, in the hate speech trial of Julius Malema, the court noted that ubuntu among other thin-

40 See: <https://en.wikipedia.org/wiki/Ubuntu_\%28philosophy\%29>. Accessed: 5 August 2015.

41 See: <https://en.wikipedia.org/wiki/Ubuntu_\%28philosophy\%29>. Accessed: 5 August 2015.

42 GADE, C. B. N. The historical development of the written discourses on ubuntu. South African Journal of Philosophy, v. 30, n.3, p. 303-329.

43 DESMOND, T. No Future without forgiveness. 1999. 
gs denotes distaste for vengeance and promotion of reconciliation; a society where high and equal value is placed on every person; a society within which dignity is a right accorded to everyone; a community where members are compassionate, humane and respect each other; good attitude towards one another and shared concern; restorative rather than retributive justice and 'favours civility and civilised dialogue premised on mutual tolerance. ${ }^{44}$. Along these lines, I will question whether giving a machine the power to decide who lives and who dies is in line with the Ubuntu notion that equal value must be placed on every human being and that every person must be treated not only with compassion but dignity.

Ubuntu philosophy was also further developed in Malawi where for example, Malawian author Thomas Msusa notes in Chichewa that 'kali kokha nkanyama, tili awiri ntiwanthu' - literally translated to mean 'when you are on your own you are as good as an animal of the wild; when there are two of you, you form a community. ${ }^{45}$. To this end the notion of Ubuntu emphasise the idea of togetherness, of recognising the similarities and values we share as human beings. On account of those similarities and values, even when one is your enemy, at no point shall you treat that person like vermin, the kind upon which you can wantonly unleash some kind of mechanised pesticide!

At the regional level, the notion of Ubuntu, togetherness and importance of the group can even be noted where the African member states drafted the human rights Charter for the continent. The charter is uniquely styled 'African Charter on Human and Peoples' rights', being the first to emphasise on 'peoples' - clearly upholding the 'I am because we are' notion. This notion of ubuntu has also found its way to other continents where it is repeatedly cited in diplomatic conferences including those that are organised by the UN.

Now that the African notion of Ubuntu is the equivalent of humanity, it is important to discuss what the place of humanity in international law. That discussion is important because it can help pinpoint where Ubuntu or humanity has already informed the formulation of

44 See Afri-Forum and Another v Malema and others, 23 (The Equality Court, Johannesburg 2011).

45 T Msusa ‘: On Malawi's 44th Independence Anniversary, Paulo Freire, Critical Pedagogy, Urban Education, Media Literacy, Indigenous Knowledges, Social Justice. certain rules even at the international law. This helps to emphasise the relevance of Ubuntu or humanity to the debate on autonomous weapon systems.

\section{UBUNTU/HUMANITY IN INTERNATIONAL LAW}

The spirit of humanity gives international law its philosophical foundation ${ }^{46}$.

For a very long time, lawyers, judges, special rapporteurs and policy makers have attempted to define what is meant by humanity or principles of humanity. At the international level, it is difficult to ascertain exactly when and where the concept of humanity originated. I have already pointed out above that on the African continent, the notion of Ubuntu or humanity as a philosophy can be traced to the colonial era in Zimbabwe. As for Europe, there is a number of scholars suggesting that it originated with Greek sophists where 'humanitas' was equated with the ability of man to reason as 'mankind's distinguishing feature. ${ }^{47}$. For example, according to Cicero, the only contrast among humans was not that of Romans and Barbarians but rather of 'humanity and inhumanity. ${ }^{48}$.

As I have already pointed out above in relation to the African continent where Ubuntu plays an important role in many government policies, trying to ascertain the definition of humanity or what it entails is not an 'academic pursuit' - it is important because the term plays an important role in the governance of armed conflict, law enforcement situations or wherever weapons are used $^{49}$. It is in this sense that Robin Coupland has noted that humanity governs the 'abilities of humans to make and use weapons and, in parallel, to restrain the use thereof. ${ }^{30}$. From a humanitarian perspective, Robin

46 See Written Statement of the Government of Japan in the Nuclear Weapons case, at p2, available at: <http://www.icj-cij.org/ docket/files/93/8768.pdf>. Accessed: 29 Jan. 2015.

47 See BLONDEL, J. L. The meaning of the word 'humanitarian' in relation to the fundamental principles of the Red Cross and Red Crescent. International Review of the Red Cross, v. 273, p. 507-515, 1989. 48 BLONDEL, J. L. The meaning of the word 'humanitarian' in relation to the fundamental principles of the Red Cross and Red Crescent. International Review of the Red Cross, v. 273, p. 507-515, 1989. 49 COUPLAND, R. Humanity: what is it and how does it influence international law? International Review of the Red Cross, v. 969 , 2001. p. 972.

50 COUPLAND, R. Humanity: what is it and how does it influence international law? International Review of the Red Cross, v. 969, 2001. p. 970. 
Coupland observes that one of the defining characteristics of human existence has been the making of, threatening with or use of weapons. ${ }^{51}$. The only determinant factor as to whether use of weapons or threat is going to be humane or inhumane is the exercise of 'restraint as to how, when and where weapons are used. ${ }^{52}$. If the international community is going to let the use of weapons or violence 'slip the leash of restraint', the results may be catastrophic for humanity ${ }^{53}$.

Notwithstanding that its meaning has not been expressly articulated, humanity has been invoked in different branches of international law like international humanitarian law, international human rights law and international criminal law. In the African Charter on Human and Peoples' Rights, humanity or Ubuntu was a major consideration that shaped many sections in the Charter. There are also a number of international organisations that have expressly stated that the principle of humanity is their operative guideline.

\subsection{Humanity and International humanitarian law}

The demand for humanity on the battle field is evident in the history of mankind. For example, it can be found in many practices of ancient states in Africa, China, India and many other regions. The main purpose of most of the rules of the battlefield was to safeguard the survival of a particular group albeit it being viewed or declared an enemy. Fighters were forbidden from engaging in acts that would cause unnecessary suffering as that was considered to be contrary to the elementary principles of humanity. Most of those ancient rules are incorporated in the current rules of IHL on means and methods of warfare. Amongst these ancient rules, some of the most interesting comes from the ancient Laws of Manu where for example, use of barbed, poisoned and fire blazing weapons, deliberately attacking those not taking part in hostilities, killing a surrendering fighter or a grievously wounded fighter was prohibited as it was

51 COUPLAND, R. Humanity: what is it and how does it influence international law? International Review of the Red Cross, v. 969, 2001. p. 971.

52 COUPLAND, R. Humanity: what is it and how does it influence international law? International Review of the Red Cross, v. 969, 2001. p. 971.

53 COUPLAND, R. Humanity: what is it and how does it influence international law? International Review of the Red Cross, v. 969, 2001. p. 971. considered to be contrary to the dictates of humanity ${ }^{54}$.

In 1864, Henry Dunant after witnessing the horrors of Solferino wrote a book titled A Memory of Solferi$n 0^{55}$. In this book, he appealed to humanity and public conscience which resulted in the drafting and adoption of the First Geneva Convention ${ }^{56}$. In the 1905 battle of Tsushima, the Japanese fleet was defeated by the Russian fleet and was left in a terrible shipwreck ${ }^{57}$. It shocked the conscience of humanity to the extent that governments agreed to have another Geneva Convention for those wounded, sick and shipwrecked at sea ${ }^{58}$.

Likewise, World War I and II saw many soldiers behind enemy lines and many were captured and millions suffered ill-treatment at the hands of their captors ${ }^{59}$. Once again, conscience and humanity played a role in the drafting of the Third Geneva Convention on Prisoners of War to address situations like those of prisoners of war in World War I and II. It is not an untold story that civilians suffered the most in World War II that in 1949, another Geneva Convention was specifically drafted to deal with the protection of civilians in armed conflict ${ }^{60}$.

The gruesome deliberate civilian attacks in the Vietnam War and rampant use of indiscriminate conventional weapons shock the conscience of the world community once again ${ }^{61}$. Added to this discourse was the quest for self-determination and wars that are fought for that right. This resulted in the two Additional Protocols to the Geneva Conventions in 1977 and the adoption of the Convention on Certain Conventional Weapons in 1980.

On account of these clear cut examples of the influence of humanity, a number of scholars note that

54 See the Laws of Manu, Rule 90-93 available at: < http://www. sacred-texts.com/hin/manu.htm>. Accessed: 31 Dec. 2014.

55 See DUNANT, J. H. A memory of Solferino: international committee of the red cross. 2006.

56 GARDAM, J. G. Non-combatant immunity as a norm of international humanitarian law. Martinus Nijhoff Publishers, 1993.

57 See Out of My Past Memoirs of Count Kokovtsov, 1935, p. 50.

58 Geneva Convention III for the Amelioration of the Condition of Wounded, Sick and Shipwrecked Members of Armed Forces at Sea. Geneva, 12 August 1949.

59 See JONES, H. Violence against prisoners of war in the First World War: Britain, France and Germany, 1914-1920. Cambridge: Cambridge University Press, 2011. p. 29-440

60 See Geneva Convention (IV) relative to the Protection of Civilian Persons in Time of War, Geneva, 12 August 1949.

61 See BOGASKI, G. American protestants and the debate over the $V i$ etnam War: Evil was loose in the world, 2014. p.12. 
humanity is the core and basis of international humanitarian law. For example, Matthee has extrapolated and nuanced the foundational basis of the law of armed conflict as follows:

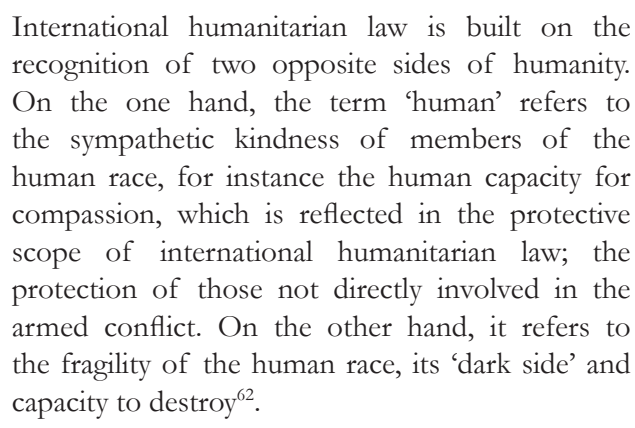

To this end, Mariëlle Matthee has observed that the 'human face is the special character of international humanitarian law itself. ${ }^{63}$. Many of the treaties and conventions in international humanitarian law are argued to have been influenced or founded on the basis of the principle of humanity as already indicated above. For example, in recognising the importance of the Martens Clause and its principles of humanity and dictates of public conscience, Peter Asaro notes that in as much as it is true that many conventions and treaties codify customary law 'by putting into writing the norms of behavior already recognised and adopted by states', in the case of IHL treaties like the Geneva Conventions, 'written law emerged specifically because the widespread behavior of states ran counter to shared moral sensibilities and collective interests. ${ }^{64}$. Thus here, humanity is seen as influencing the adoption of certain laws even though it was not supported by state practice. To this end, the role of humanity in IHL as far as the making of laws and norms cannot be under-estimated.

In international humanitarian law treaties, the concept of humanity first appeared late in the $19^{\text {th }}$ century specifically in the 1868 Saint Petersburg Declaration ${ }^{65}$.

62 MATTHEE, $M$ et al. Armed conflict and international law: in search of the human face: Liber Amicorum in Memory of Avril McDonald, 2013. p. 16.

63 MATTHEE, $\mathrm{M}$ et al. Armed conflict and international law: in search of the human face: Liber Amicorum in Memory of Avril McDonald, 2013. p. 16.

64 ASARO, P. Jus nascendi, robotic weapons and the Martens Clause. Forthcoming, v. 14, 2015. p.3.

65 The declaration stated that states 'having by common agreement fixed the technical limits at which the necessities of war ought to yield to the requirements of humanity, the undersigned are authorized by the orders of their Governments to declare as follows: Considering that the progress of civilization should have the effect of alleviating as much as possible the calamities of war: That the
Robin Coupland notes that it is surprising that states chose to invoke the concept of humanity and include it in the St Petersburg Declaration when its meaning was not ascertained ${ }^{66}$. It was after 31 years later that humanity was expressly referred to again in the First Hague Peace Conference in 1899. From henceforth, almost all the treaties and legal documents relating to the laws of war contained the concept of humanity ${ }^{67}$. JC Boogard has observed that the rules of international humanitarian law 'aim to preserve a sense of humanity in armed conflict. ${ }^{68}$. All other rules of international humanitarian law, observes Hanna Brollowski, 'merely function as means to actualise humanity. ${ }^{69}$.

Before the inclusion of the term humanity in the laws of war, there was always an attempt by belligerents to treat their enemies as less human or 'outside the human race. ${ }^{70}$. Even after the emergence of the term humanity in the laws of war and human rights, perpetrators of heinous acts always seek to exclude the perceived enemy from the human race for the easiness of committing crimes. In Rwandese genocide for example, certain groups were called names such as inyenzi- meaning cockroach or inzoka - meaning snake in Kinyarwanda ${ }^{71}$. This was a clear attempt to dehumanise them

only legitimate object which States should endeavour to accomplish during war is to weaken the military forges of the enemy; That for this purpose it is sufficient to disable the greatest possible number of men; That this object would be exceeded by the employment of arms which uselessly aggravate the sufferings of disabled men, or render their death inevitable; That the employment of such arms would, therefore, be contrary to the laws of humanity; The Contracting Parties engage mutually to renounce, in case of war among themselves, the employment by their military or naval troops of any projectile of a weight below 400 grammes, which is either explosive or charged with fulminating or inflammable substances.

66 COUPLAND, R. Humanity: what is it and how does it influence international law? International Review of the Red Cross, v. 969, 2001. p. 973.

67 See for example Article 76 of the Lieber Code (1863); Article 3 Common to the Geneva Conventions; Article 12 of Geneva Convention I; Article 12 of Geneva Convention II; Article 13 of Geneva Convention III; Article 27 of Geneva Convention IV; Article 75 (1) of Additional Protocol I; Article 4(1) of Additional Protocol II. 68 BOOGARD, J. C. Fighting by the principles: principles as a source of international humanitarian law. In: MATTHEE, M. et. al. (Ed.). Armed conflict and international humanitarian law: in search for the human face. Springer Science \& Business Media, 2013. p. 4. 69 BROLLOWSKI, H. Military robots and the principle of humanity. In: MATTHEE, M. et. al. (Ed.). Armed conflict and international humanitarian law: in search for the human face. Springer Science \& Business Media, 2013. p. 69.

70 See SCHMITT, C. The concept of the political. Chicago: University of Chicago Press, 2007. p. 54.

71 TIRRELL, L. Genocidal language games, 2009. p. 176. Available 
or remove them from the humankind. To this, William Schabas observed that 'the road to genocide in Rwanda was paved with hate speech' - a clear lack of humanity and dehumanisation of another group ${ }^{72}$. This was also the same case in conflicts that are motivated by racial differences, for example, apartheid in South Africa. Parts of the infamous speech of Botha read as follows:

The fact that, blacks look like human beings and act like human beings do not necessarily make them human beings. Hedgehogs are not porcupines and lizards are not crocodiles because they look alike ${ }^{73}$.

Likewise, Jan Joerden observes that after the Holocaust, the notion of human dignity was placed at the beginning of the new 'German Constitution to underline its importance, especially after the Nazi era during which humanity, both of the individual and of mankind altogether, was completely set aside. ${ }^{94}$. Humanity in this regard, is a concept 'that excludes the concept of the enemy'; if there is an enemy for example in armed conflict, 'the enemy does not cease to be a human being' thus the need to treat them humanely ${ }^{75}$.

It can also be deduced that the regulation of means and methods of warfare is greatly influenced by consideration of humanity. For example, Avril McDonald observes that the law of armed conflict is 'called international humanitarian law not because it is obvious that humanity should exist in war but because it is not obvious at all to those who fight these wars. ${ }^{76}$. Humanity in this sense is there to restrain the 'most barbaric of human activities' during a time when it seems there is a 'natural human tendency to lose all inhibitions when fighting in armed conflict. ${ }^{77}$.

at: <https://www.academia.edu/905194/Genocidal_Language_ Games>. Accessed: 4 Feb. 2015.

72 SCHABAS, W. Hate speech in Rwanda: the road to genocide. Mc Gill Law Journal, v. 144, 2000.

73 See <http://ireport.cnn.com/docs/DOC-813552>. Accessed: 4 Feb. 2015.

74 JOERDEN, J. C. The promise of human dignity and some of its juridical consequences especially for medical criminal law. In: BEERS, B. et. al. (Ed.) Humanity across international law and biolaw. Cambridge: Cambridge University Press, 2014. p. 217.

75 SCHMITT, C. The concept of the political. Chicago: University of Chicago Press, 2007. p. 54.

76 MCDONALD, A. Hors de combat: post-September 11 challenges to the rules. In: HENSEL, H. M. (Ed.). The legitimate use of military force: the just war tradition and the customary law of armed conflict. Ashgate Publishing, 2008. p. 244.

77 MCDONALD, A. Hors de combat: post-September 11 challenges to the rules. In: HENSEL, H. M. (Ed.). The legitimate use of military force: the just war tradition and the customary law of armed conflict. Ashgate Publishing, 2008. p. 244.
For humanitarian reasons, 'international humanitarian law, as most particularly shown in its rules protecting persons hors de combat, is a statement of the extent, and limits, of our humanity in war. ${ }^{78}$. In summary of the rules that govern the means and methods of warfare as contained in the Martens Clause, one United Nations Special Rapporteur on the situation in Kuwait noted as follows:

The right of parties to choose the means and methods of warfare is not unlimited, i.e the right of parties to choose the means of injuring the enemy, is not unlimited;

A distinction must be made between persons participating in military operations and those belonging to the civilian population to the effect that the latter be spared as much as possible;

It is prohibited to launch attacks against the civilian population as such ${ }^{79}$.

Courts have also found violations of international humanitarian law on the basis that the conduct in question was inconsistent with the principles of humanity. For example, in the case of Military and Paramilitary Activities in and against Nicaragua, the ICJ found that the conduct of the US was contrary to general principles of IHL since they violated 'elementary considerations of humanity. ${ }^{90}$. The ICJ had earlier noted that consideration of humanity as part of the general principles of international law was not only applicable to the conduct of hostilities ${ }^{81}$ but even in times of peace ${ }^{82}$. It was for that reason that in 1996 the United Nations Security Council censured the use of excessive force against civilian aircraft observing that the use of certain weapons against civilian aircraft is 'incompatible with the elementary considerations of humanity. ${ }^{83}$.

It is in the same vein that Mr. Boutros Boutros-Gha-

78 MCDONALD, A. Hors de combat: post-September 11 challenges to the rules. In: HENSEL, H. M. (Ed.). The legitimate use of military force: the just war tradition and the customary law of armed conflict. Ashgate Publishing, 2008. p. 248.

79 E/CN.4/1992/26. Report of the United Nations Special Rapporteur on the situation of human rights in Kuwait under Iraq occupation, Walter Kälin, 1992.

80 MILITARY and Paramilitary Activities in and against Nicaragua, Nicaragua v the United States of America ICJ Reports 1986

81 See the Corfu Channel case, United Kingdom v Albania, Merits, ICJ Reports (1949).

82 See the Corfu Channel case, United Kingdom v Albania, Merits, ICJ Reports (1949).

83 Security Council Resolution 1067, para 6, 28 July 1996. 
li, the former United Nations Secretary General observed that it does not matter whether it is an international or non-international armed conflict; prohibitions that are in Common Article 3 to the Geneva Conventions resonate from those acts that are contrary to the 'elementary considerations of humanity. ${ }^{94}$.

The ability to recognise and respect the human dignity and worthy of another person is the basis on which the society and international community can survive. As has been observed by Thomas Hobbes in the $17^{\text {th }}$ century, that respect must continue even in time of war, governing the way humans conduct themselves and consequently the weapons they use.

\begin{abstract}
Whatsoever therefore is the consequent to a time of war, where every man is enemy to every man [therefore no respect for humanity]... wherein men live without security, than what their own strength and their own invention shall furnish them withal [then]...there is no arts; no letters; no society; and which is worst of all, continual fear, and danger of violent death; and the life of man, solitary, poor, nasty, brutish and short ${ }^{85}$.
\end{abstract}

From the foregoing, the United Nations, courts, commentators and treaty drafters believe in the importance of the principle of humanity in international humanitarian law albeit it not being specifically defined. This is the same under international human rights law.

\subsection{Humanity and human rights law}

Under human rights law, B Beers has observed that human rights only become meaningful if they are understood from a point of humanity ${ }^{86}$. Peter Asaro has thus linked humanity to the Universal Declaration of Human Rights noting that many conventions on human rights are in essence influenced by the concept of humanity ${ }^{87}$. He notes that the UDHR is underpinned by humanity, a 'set of moral principles' and 'a hybrid of shared beliefs, sentiments, and attempts to derive principles from norms of belief and behavior' common to all peoples that have been subsequently codified in

84 Report of the UN Secretary General, Boutros Boutros-Ghali, UN Doc. S/25704 (1993) para 48.

85 See HOBBES, T. Leviathan. 2010. p. 56-57.

86 BEERS, B. et al. Humanity across international law and biolaw. Cambridge: Cambridge University Press, 2014. p. 177; See also TEITEL, R. G. Humanity's law. Oxford: Oxford University Press, 2011.

87 ASARO, P. Jus nascendi, robotic weapons and the Martens Clause. Forthcoming, v. 14, 2015. p.5. various human rights treaties and conventions ${ }^{88}$. There are a number of human rights treaties that refer to either the principle of humanity or human dignity as part of humanity ${ }^{89}$. Likewise, the United Nations Human Rights Committee has emphasised the importance of the principle of humanity in some of its General Comments ${ }^{90}$. In General Comment 21 for example, it is categorically stated that:

Treating all persons deprived of their liberty
with humanity and with respect for their dignity
is a fundamental and universally applicable rule.
Consequently, the application of this rule, as a
minimum, cannot be dependent on the material
resources available to the State party. This rule must
be applied without distinction of any kind, such
as race, colour, sex, language, religion, political or
other opinion, national or social origin, property,
birth or other status ${ }^{91}$.

Thus in human rights law, it is considered settled practice that 'the treatment dispensed to human beings, in any circumstances, ought to abide by the principle of humanity which permeates the whole corpus juris of the international protection of the rights of the human person. ${ }^{92}$. Nevertheless, just like in the case of international humanitarian law, there is no express definition of humanity in the human rights law regime.

\subsection{Humanity and international criminal law}

Again, a reference to humanity is present in international criminal law. The preamble of the Rome Statute states that the international community is 'mindful that during this century millions of children, women and men have been victims of unimaginable atrocities that deeply shock the conscience of bumanity. ${ }^{93}$. To the same end, courts have considered principles of humanity in

88 ASARO, P. Jus nascendi, robotic weapons and the Martens Clause. Forthcoming, v. 14, 2015. p.5.

89 Article 17(1) of the Convention on the Protection of Migrant Workers; Article 5 of the African Charter on human and Peoples' Rights; Article 37(b) of the Convention on the Rights of the Child; Article 5 of the American Convention on Human Rights.

90 UN Doc. HRI/GEN/1/Rev.1, Human Rights Committee, General Comment 9, Article 10, para 3 stating in pat that 'allowing visits (for those deprived of liberty), in particular by family members, is normally also such a measure which is required for reasons of humanity.'

91 UN Doc. HRI/GEN/1/Rev.1 at 33, Human Rights Committee, General Comment 21, Article 10, para 4.

92 KOLB, R.; GAGGIOLI, G. Research handbook on human rights and humanitarian law. Edward Elgar Publishing, 2013. p. 189.

93 Pre-amble of the Rome Statute. 
the adjudication of some cases. In the case of Furundziya, the International Criminal Tribunal for the Former Yugoslavia stated that torture is not only contrary to customary international law but also principles of humanity as enshrined in the Martens Clause ${ }^{94}$. The ICTY also observed that deliberate attacks on the civilian population are contrary to the elementary consideration of humanity as derived from the Martens Clause ${ }^{95}$.

It is in the light of the concept of humanity that in international criminal law 'crimes against humanity' were coined ${ }^{96}$. In this term, humanity is considered to be both the humankind and the ideologies and norms of the humankind ${ }^{97}$. Thus a person committing crimes against humanity commits acts that shock the human conscience in that they are against the ideologies and universal or widely agreed norms of the humankind thereby offending both the descriptive understanding of humanity as mankind and the normative understanding of humanity as the value that is shared by all human beings ${ }^{98}$.

In the same vein, in international criminal law, the application of statutory limitations to war crimes is considered to be an affront 'to world public opinion' and humanity since it fuels impunity9. Likewise, emerging international norms such as the responsibility to protect (RtoP) are premised on humanity and public conscience- where governments, albeit human rights violations not occurring against their own citizens or within their territories, they reserve a right and obligation to intervene and protect civilians were the state responsible is either unwilling or unable to protect ${ }^{100}$.

94 See PROSECUTOR v Furundziya (1998) Judgement No. IT95-17/1-T para 137.

95 See PROSECUTOR v Martic (1996), Review of the Indictment Pursuant to Rule 61, No. IT-95-11-R61 para 48.

96 BASSIOUNI, M. C. Crimes against humanity: historical evolution and contemporary application. Cambridge: University Press, 2011. p. 10.

97 See MACLEOD, C. Towards a philosophical account of crimes against humanity. European Journal of International Law, p. 281302, 2010 .

98 See MACLEOD, C. Towards a philosophical account of crimes against humanity. European Journal of International Law, p. 281-302, 2010.; URUENA, R. Deciding what is humane: towards a critical reading of humanity as a normative standard in international law. In: BEERS, B. et. al. (Ed.). Humanity across international law and biolaw. Cambridge: Cambridge University Press, 2014.

99 Convention on the Non-Applicability of Statutory Limitations to War Crimes and Crimes Against

Humanity, 26 November 1968

100 See PATTISON, J. Humanitarian intervention and the responsibility to protect: who should intervene? Oxford: Oxford University Press,
According to Michael Veuthey, humanity involves 'demanding justice through criminal prosecution before national or international courts. ${ }^{101}$. In other words, it is in line with humanity that that where a crime is committed, the perpetrator must be prosecuted and the victim remedied ${ }^{102}$. Now, this point is linked to the argument that AWS may create an accountability vacuum where it may be impossible to hold anyone responsible for a crime committed ${ }^{103}$.

\subsection{NGOs, international organisations and humanity}

There are many international organisations who consider their work to be humanitarian, indeed, they see the number one objective of their work being to further and protect humanity. An example of such an organisation is the International Committee of the Red Cross which has humanity as one of its operating principles. Indeed, humanity is even the raison d'etre of the ICRC if one considers the history of its foundation ${ }^{104}$.

The principle of humanity stands out on its own in the doctrine of the Red Cross, and all the other principles hang from it. It is the fundamental basis of our institution, indicating both its ideal, the reason for its existence and its object. If the Red Cross were to have only one principle, this would be $\mathrm{it}^{105}$.

Thus in its humanity principle, the ICRC considers that it was 'born of a desire to bring assistance without discrimination to the wounded on the battlefield', 'alleviate human suffering' by protecting lives and the health of those caught in the maelstrom of armed conflict and 'ensure respect for the human being' while promoting 'mutual understanding, friendship, co-operation and

\section{0.}

101 VEUTHEY, M. Public conscience in international humanitarian law today. In: HORST, F. et. al. (Ed.). Krisensicherung und humanitärer schut: crisis management and humanitarian protection. Berliner Wissenschaftsverlag, 2004. p. 626.

102 VEUTHEY, M. Public conscience in international humanitarian law today. In: HORST, F. et. al. (Ed.). Krisensicherung und humanitärer scbutz: crisis management and humanitarian protection. Berliner Wissenschaftsverlag, 2004. p. 626.

103 See GENEVA ACADEMY OF INTERNATIONAL HUMANITARIAN LAW. Autonomous weapon systems under international law. Academy Briefing Number, v. 24, iss. 8, 2014.

104 See BROLLOWSKI, H.'Military robots and the principle of humanity. In:MATTHEE, M. et al (Ed.). Armed confict and international bumanitarian law: in search for the human face. 2013. p. 69.

105 PICTET, J. S. Humanity. International Review of the Red Cross, v. 158, 1995. 
lasting peace amongst all peoples. ${ }^{306}$.

Notwithstanding that humanity is provided for in international humanitarian law, UN law, human rights law, international criminal law and founding documents of important international organisations, there is no express definition of what it is. This has prompted some scholars to argue that it is a vague term and as such the Martens Clause which contains it cannot be relied upon in the AWS debate ${ }^{107}$. Nevertheless, the fact that no express definition is provided does not necessarily mean that the term is incapable of meaning.

\subsection{Definition of humanity}

As already highlighted above, there is so single definition of what the term humanity means ${ }^{108}$. B Beers has noted that an attempt to define humanity is usually characterised by a 'wide-spread tendency to translate particular and provisional moral convictions into universal truths and symbols by identifying one's own ways with the ways of humanity as a reified whole. ${ }^{109}$. According to Hanna Brollowski, 'to define the concept of humanity is in itself a daunting task. ${ }^{110}$. In general, however, Avril McDonald has observed that humanity and international humanitarian law can be said to be summarised in the popular phrase 'do unto others as you would have them do unto you. ${ }^{111}$.

\subsection{Literal definition of humanity}

The ordinary, literal or grammatical definition of humanity should be the first port of call ${ }^{112}$. The literal and

106 DURAND, A. The International Committee of the Red Cross. 1981. p. 54.

107 See EVANS, T. D. Note at war with the robots: autonomous weapon systems and the Martens Clause. Hofstra Law Review, v. 697, iss. 41,2014

108 URUENA, R. Deciding what is humane: towards a critical reading of humanity as a normative standard in international law. In: BEERS, B. et. al. (Ed.). Humanity across international law and biolaw. Cambridge: Cambridge University Press, 2014. p. 181.

109 BEERS, B. et al. Humanity across international law and biolaw. 2014. p. 177.

110 BROLLOWSKI, H.'Military robots and the principle of humanity. In:MATTHEE, M. et al (Ed.). Armed conflict and international bumanitarian law: in search for the human face. 2013. p. 68.

111 MCDONALD, A. Hors de combat: post-September 11 challenges to the rules. In: HENSEL, H. M. (Ed.). The legitimate use of military force: the just war tradition and the customary law of armed conflict. Ashgate Publishing, 2008. p. 243.

112 BROLLOWSKI, H. Military robots and the principle of hu- descriptive meaning of humanity refers to 'humankind, that is, to the group of men and women who form the human race. ${ }^{113}$. This literal understanding of humanity as meaning humankind is also present in case law. For example, in the Nicaragua case, the court noted that if certain rules of international law are not respected, it will lead to disastrous consequences causing untold misery to humanity. ${ }^{314}$. In this sense, humanity is human kind. This literal understanding of the term humanity relevant to international law since international law, in the first place, 'is not made for anyone else but for the human race: international law is, in that sense, humanity's law."115.

Literally, humanity is also understood to refer to 'the character or quality of being humane; behaviour or disposition towards others such as befits a human being." ${ }^{116}$. Jean Pictet has thus defined humanity as 'a sentiment of active goodwill towards mankind' that encompasses 'a complex motive in which kindred elements such as kindness, pity, gentleness, generosity, patience, and mercy, are present in varying degrees. ${ }^{317}$. There is usually a link between these two literal definitions of humanity although it should be noted that 'human existence is not necessarily associated with humane behaviour of individuals. ${ }^{118}$.

\subsection{Defining humanity as a normative standard}

The more important definition of humanity as according to Rene Uruena, is to understand it 'as a normative

manity. In: MATTHEE, M. et al (Ed.). Armed conflict and international humanitarian law: in search for the human face. 2013. p. 68. 113 URUENA, R. Deciding what is humane: towards a critical reading of humanity as a normative standard in international law. In: BEERS, B. et. al. (Ed.). Humanity across international law and biolaw. Cambridge: Cambridge University Press, 2014. p. 180; R Coupland 'Humanity: What is it and how does it influence international law?' (2001) International Review of the Red Cross 969.

114 MILITARY and Paramilitary Activities in and against Nicaragua, Nicaragua v the United States of America ICJ Reports 1986, pp. 143 and 146, Separate Opinion of President Nagendra Singh.

115 URUENA, R. Deciding what is humane: towards a critical reading of humanity as a normative standard in international law. In: BEERS, B. et. al. (Ed.). Humanity across international law and biolaw. Cambridge: Cambridge University Press, 2014. p. 180.

116 See COUPLAND, R. Humanity: what is it and how does it influence international law? International Review of the Red Cross, v. 969, 2001.

117 PICTET, J. S. Humanity. International Review of the Red Cross, v. 158,1995 .

118 See COUPLAND, R. Humanity: what is it and how does it influence international law? International Review of the Red Cross, v. 969, 2001. p. 972. 
standard' that presents a somewhat 'empty vessel that empowers humanitarian institutions and their expertise' to have the 'last word on what humane behaviour really is' in each particular circumstance ${ }^{119}$. This is where values that have been long accepted by humankind are of importance in shaping what is meant by humanity.

Thus when trying to find the meaning of what is meant by the term humanity in terms of the laws of armed conflict, it should be understood that 'humanity is linked to the idea of humane treatment - be it of the ill or the wounded, of non-combatants or of others whose protection is mandated. ${ }^{120}$. In this sense, a question on whether certain conduct is consistent with requirements of humanity is the equivalent of whether your conduct is humane ${ }^{121}$.

From the above understanding, humanity must be viewed as 'a standard that's serves as a yardstick to evaluate a certain conduct.'122 In showing the close link between humanity, human dignity and other moral standards or yardsticks that appear to be universal to humankind, Coupland observes that:

\begin{abstract}
Humanity-sentiment, limiting inhumanity, a collective human conscience, respecting human rights, the restraint of armed violence and ... morality are so closely knit within our psychology that they may only bear different names because of the poverty of language. ${ }^{123}$
\end{abstract}

This view is supported by many scholars who postulate that human rights are born out of human dignity. ${ }^{124}$ In other words, human dignity is the mother of all ri-

119 URUENA, R. Deciding what is humane: towards a critical reading of humanity as a normative standard in international law. In: BEERS, B. et. al. (Ed.). Humanity across international law and biolaw. Cambridge: Cambridge University Press, 2014. p.178.

120 URUENA, R. Deciding what is humane: towards a critical reading of humanity as a normative standard in international law. In: BEERS, B. et. al. (Ed.). Humanity across international law and biolaw. Cambridge: Cambridge University Press, 2014. p.180.

121 URUENA, R. Deciding what is humane: towards a critical reading of humanity as a normative standard in international law. In: BEERS, B. et. al. (Ed.). Humanity across international law and biolaw. Cambridge: Cambridge University Press, 2014. p. 180.

122 URUENA, R. Deciding what is humane: towards a critical reading of humanity as a normative standard in international law. In: BEERS, B. et. al. (Ed.). Humanity across international law and biolaw. Cambridge: Cambridge University Press, 2014. p. 181.

123 COUPLAND, R. Humanity: what is it and how does it influence international law? International Review of the Red Cross, v. 969, 2001. p. 978.

124 MACCORMICK, N. Legal right and social democracy: essays in legal and political philosophy. Clarendon Press, 1982. p. 154. ghts. ${ }^{125}$ Many human rights treaties refer to the right to dignity or the importance of the dignity of the human person. ${ }^{126}$. McCrudden has observed that the importance of human dignity when human rights treaties were being negotiated and drafted as that of providing 'a theoretical basis for the human rights movement in the absence of any other basis for consensus. ${ }^{127}$.

To this end, 'an individual is capable of having rights if and only if his well-being is of ultimate value. ${ }^{128}$. According to this view, humanity then is that which is consistent with human dignity ${ }^{129}$. The only problem arise in that there is not much consensus in what exactly human dignity entails irrespective of the fact that many scholars emphasise its importance and it being the basis of other rights ${ }^{130}$.

Nevertheless, the understanding of humanity as a normative standard that incorporate human dignity is that it is not only concerned with the protection of the individual but human kind as a whole. The Constitutional Court of German has articulated that 'human dignity means not only the individual dignity of the person but the dignity of man as a species. ${ }^{131}$.

The advantage of taking the principle of humanity as a normative standard is that it is not rigid; it 'allows a contextual assessment of situations, and permits flexibility while invoking a certain normative value. ${ }^{132}$. From the view of international law which is ever changing, humanity and dignity, it is argued, must not be given a 'concrete meaning' since that would empower those

125 BARAK, A. Human dignity. Cambridge: Cambridge University Press, 2015. p. 104.

126 See for example Article 1 of UDHR; preamble to UN Charter; see also case of Tyrer $v$ UK ECHR (1978)2.

127 MCCRUDDEN, C. Human dignity and judicial interpretation of human rights. European Journal of International Law, v. 655, n. 19, 2008. p. 655-77.

128 RAZ, J. The morality of freedom. 1986. p. 166.

129 URUENA, R. Deciding what is humane: towards a critical reading of humanity as a normative standard in international law. In: BEERS, B. et. al. (Ed.). Humanity across international law and biolaw. Cambridge: Cambridge University Press, 2014. p. 184.

130 See generally KRETZMER, D.; KLEIN, E. The concept of buman dignity in buman rights discourse. Kluwer Law International, 2002.

131 See URUENA, R. Deciding what is humane: towards a critical reading of humanity as a normative standard in international law. In: BEERS, B. et. al. (Ed.). Humanity across international law and biolaw. Cambridge: Cambridge University Press, 2014. p. 188.

132 See URUENA, R. Deciding what is humane: towards a critical reading of humanity as a normative standard in international law. In: BEERS, B. et. al. (Ed.). Humanity across international law and biolaw. Cambridge: Cambridge University Press, 2014. p.189. 
who seek to interpret it in a negative way that demean human rights when circumstances change ${ }^{133}$. An example of such an interpretation is where Evans argues that Human Rights Watch missed the point on how to interpret humanity in its 2012 report titled Losing Humanity: The case against killer robots ${ }^{134}$. He argues that 'a literally inhuman weapon system may prove to be far more humane than human soldiers could ever be. ${ }^{\prime 135}$. Such an argument could be well supported if there was a rigid definition of what constitutes humanity. However, because the concept is flexible, Evans' argument can be attacked from all angles, starting with the fact that the moment a weapon is termed to be inhuman, and then, the game is over.

As already noted above, Evans's arguments seem to advocate for the strengthening of states' powers to make decisions on the international level through exclusion of the Martens Clause and its humanity principles and dictates of public conscience. Schmitt has observed that in most cases where sovereigns or states invoke the principle of humanity to support their argument, it is not out of sincerity, thus in his opinion and as far as states are concerned, 'whoever invokes humanity wants to cheat. ${ }^{136}$.

In the same vein, Erika de Wet has noted that one of the fundamental roles of humanity, understood as a normative standard, is that it provides 'a constitutional limit' to the powers of states at the global level ${ }^{137}$. Such a constitutional limit is not rigid but flexible depending on the circumstances. In regards to flexibility of humanity and its importance, Uruena observes as follows:

When everything fails, when the Security Council or the legal departments of Foreign Offices are entangled in discussions of vetoes, or arcane treaty provisions, the ethical imperative of humanity

133 See URUENA, R. Deciding what is humane: towards a critical reading of humanity as a normative standard in international law. In: BEERS, B. et. al. (Ed.). Humanity across international law and biolaw. Cambridge: Cambridge University Press, 2014. p. 189.

134 EVANS, T. D. Note at war with the robots: autonomous weapon systems and the Martens Clause. Hofstra Law Review, v. 697, iss. $41,2014$.

135 EVANS, T. D. Note at war with the robots: autonomous weapon systems and the Martens Clause. Hofstra Law Review, v. 697, iss. $41,2014$.

136 SCHMITT, C. The concept of the political: expanded edition. 2008. p. 54. He notes for example that in the past states have used the principle of humanity to extend their borders while crushing the sovereignty of other states.

137 DE WET, E. The international constitutional order. International and Comparative Law Quarterly, v. 55, 2006. p. 51. seems to trump all discussions. Humanity is out there, not in an office in Geneva or New York - but in Colombia, or Sudan, or some other place where the dignity if human beings needs to be protected by the international community as a whole ${ }^{138}$.

Thus while the literal meaning of humanity is important, when understood as a normative standard, humanity becomes clearer but at the same time flexible. Other commentators have suggested that humanity can be defined in terms of other disciplines other than law. In view of the multi-disciplinary nature of the AWS debate, such an approach is also welcome.

\subsection{Defining humanity terms of other disciplines other than law}

While Coupland recognises that there is much ambiguity as far as the term humanity is concerned in international law, he notes that in other disciplines such as security studies, health sciences like psychology, the meaning of humanity may be clear cut. To that end, he suggests that to find the meaning of humanity, one may resort to 'interpreting humanity in terms of security and health. ${ }^{139}$. To justify why humanity must be interpreted in terms of health and security when it comes to weapons, Coupland argues that 'weapons are the principal means by which personal security is eroded and therefore must be recognized as both security and health issues. ${ }^{140}$.

Humanity arises from and signifies restraining the
capacity for armed violence and limiting its effects
on security and health... Humanity interpreted
in these terms encompasses humanitarianism,
morality, development, human rights and human
security[...] Humanity is not solely the domain of
"humanitarian" agencies or international lawyers.
Other disciplines, especially those based on life
sciences, can be brought to bear[...] humanity is
a universal ethic and should be shared between all

138 See URUENA, R. Deciding what is humane: towards a critical reading of humanity as a normative standard in international law. In: BEERS, B. et. al. (Ed.). Humanity across international law and biolaw. Cambridge: Cambridge University Press, 2014. p.189.

139 COUPLAND, R. Humanity: what is it and how does it influence international law? International Review of the Red Cross, v. 969, 2001. p. 979.

140 COUPLAND, R. Humanity: what is it and how does it influence international law? International Review of the Red Cross, v. 969, 2001. p. 982; See also ABASS, A. Protecting human security in Africa. 2010. p. 64; KALDOR, M. H.; BEEBE, S. The ultimate weapon is no weapon: human security and the new rules of war and Peace. PublicAffairs, 2010. KALDOR, M. Human security. 2013; CHANDLER, D.; HYNEK, N. Critical perspectives on buman security: rethinking emancipation and power in international relations. Routledge, 2010. 
people involved with the process of going to war $^{141}$.

Thus, to determine whether a particular conduct or weapon is inhumane; one may assess it in terms of its impact on security and health. He adds that maintenance of peace and security and protection of health is the 'lowest common denominator' that can tell what is humane and what is inhuman ${ }^{142}$.

Security is the foundation on which all human relations are based. For this reason, the international community has never stopped in its quest to keep at bay all those who are viewed to be a menace to world peace and to keep in check all conduct that may disturb world peace. Establishment of methods such as the Congress System of 1815 and its principle of balance of power, the League of Nations and the current United Nations have all been efforts of humanity to ensure that there is peace and security.

To this end, the question may be asked whether development of AWS is in the interest of security for example. The debate on AWS is sometimes obscured by an over emphasis of the importance of this kind of technology to states. In this regard, it should be understood that there is a difference between state and individual security as has been observed by Robert Jackson:

We should distinguish between personal security
and national security. Personal security is a basic
value because it is an essential requirement, or
condition, of a successful and fulfilling existence:
it liberates people (both physically and mentally)
to get on with the business of building their lives
without undue fear of those around them. Personal
security is our individual insulation from threat,
danger, or harm the source of which is always other
people. It is also peace of mind: liberation from the
anxiety and apprehension associated with fear of
those who are in a position to harm us ${ }^{143}$.

There have been arguments by some commentators that AWS will lower the threshold on the use of force ${ }^{144}$.

141 COUPLAND, R. Humanity: what is it and how does it influence international law? International Review of the Red Cross, v. 969, 2001. p. 988-989.

142 COUPLAND, R. Humanity: what is it and how does it influence international law? International Review of the Red Cross, v. 969, 2001. p. 979-988.

143 JACKSON, R. The global covenant: human conduct in a world of states. Oxford University Press, 2000. p. 186.

144 See ASARO, P. How just could a robot war be? In: BREY P. et. al. (Ed.). Current issues in computing and philosophy. IOS Press, 2008.; KHAN, P. W. The paradox of riskless warfare. Faculty Scholarship Series, v. 4, n. 326, 2002. Available at: < http://digitalcommons.law.yale. edu/fss_papers/326>.
In this sense, the AWS may be seen to potentially threaten the security of humanity and of course associated health rights. However, this may not be straightforward as it may seem. This is so because weapons can be both a means to erode security and a means to guarantee it $^{145}$.

In terms of the protection of the right to life, Heyns has noted that one of the layers of protection of the right to life is through jus ad bellum - the law relating to the use of force which is directly linked to security issues. ${ }^{146}$ Along the same lines, Pierre Perrin, a Chief Medical Officer with the ICRC has observed the importance of security for the safeguard of both public health and right to dignity as an element of humanity ${ }^{147}$. He noted that the right to health, dignity of individuals may only be effectively protected if 'the security of victims of armed conflict is guaranteed' since 'security embraces the sustainable satisfaction of needs and respects basic rights of human beings ${ }^{148}$.

If it is agreeable that 'the ultimate goal of humanity, human rights and humanitarian intervention' is to promote human security and health, then humanity can be interpreted in light of the concepts of security and health ${ }^{149}$. Humanity, therefore, is 'people living together in a state of security and health.' 150 The overall consideration when interpreting and trying to find the definition of humanity is to remember that humanity must be 'interpreted in terms of people's security and well-being.' ${ }^{151}$.

Both the literal and normative meaning of the term humanity - i.e. humanity as referring to mankind and

145 COUPLAND, R. Humanity: what is it and how does it influence international law? International Review of the Red Cross, v. 969, 2001. p. 980.

146 A/68/30532, Report of the Special Rapporteur on extrajudicial, summary or arbitrary executions, Christof Heyns, 12 August 2013, para 23.

147 PERRIN, P. War and public bealth: extending the concept of public health for the victims of armed conflict. 1998. Available at: <http://www.who.int/hac/about/6676.pdf>.

148 PERRIN, P. War and public bealth: extending the concept of public health for the victims of armed conflict. 1998. Available at: $<$ http://www.who.int/hac/about/6676.pdf>.

149 COUPLAND, R. Humanity: what is it and how does it influence international law? International Review of the Red Cross, v. 969, 2001. p. 984.

150 COUPLAND, R. Humanity: what is it and how does it influence international law? International Review of the Red Cross, v. 969, 2001. p. 986.

151 COUPLAND, R. Humanity: what is it and how does it influence international law? International Review of the Red Cross, v. 969, 2001. p.. 
humanity as a quality of being humane - play an important role in international law - sometimes applying at the same time $e^{152}$. In the end, no matter the various views that may exist as far as the issue of humanity is concerned, no matter how one might feel about it being applied in the AWS debate, 'we have to live with the fact that international law decided to invest all its capital in the empty [yet full] vessel of humanity as a normative concept - there is no changing that. Perhaps turning to the good sense of those defining humanity is the only road left. ${ }^{\prime 153}$ In this sense, humanity remains 'a platform for emancipation and justice' - more fully, in this AWS debate, it should be a guiding $\operatorname{star}^{154}$.

In discussing the relevance of the notion of humanity to the AWS debate, reference has been given to human dignity which stands as a component of humanity. The fundamental question that I seek to answer now is what is meant by human dignity and how does AWS measure to it.

\subsection{Human dignity}

\begin{abstract}
Human dignity is the humanity of a person. It is her humanity as a free being, with unbridled autonomy. It is her freedom to write her life story. This humanity expresses the conception of a person as an end and rejects viewing her as a mere means. This humanity is the framework of society. ${ }^{155}$
\end{abstract}

There are a number of scholars who have written on dignity $^{156}$. Yale Law School Professor Aharon Barak has

152 See BROLLOWSKI, H. Military robots and the principle of humanity. In: MATTHEE, M. et al (Ed.). Armed conflict and international humanitarian law: in search for the human face. 2013. p. 68.

153 See also URUENA, R. Deciding what is humane: towards a critical reading of humanity as a normative standard in international law. In: BEERS, B. et. al. (Ed.). Humanity across international law and biolaw. Cambridge: Cambridge University Press, 2014. p.195.

154 See also URUENA, R. Deciding what is humane: towards a critical reading of humanity as a normative standard in international law. In: BEERS, B. et. al. (Ed.). Humanity across international law and biolaw. Cambridge: Cambridge University Press, 2014. p.195.

155 BARAK, A. Human dignity. Cambridge: Cambridge University Press, 2015. p. 24.

156 See for example EBERLE, E. J. Dignity and liberty: constitutional visions in Germany and the United States. Praeger, 2002. WALDRON, J. Dignity, rank, and rights. Oxford University Press, 2012.; MEYER, M.; PARENT, W. The constitution of rights: human dignity and American values London. Cornell University Press, 1992. KRETZMER, D.; KLEIN, E. The concept of buman dignity in buman rights discourse. Kluwer Law International, 2002. KRAYNAK, R. P.; TINDER, G. E. In defense of human dignity: essays for our times. Paris: University of Notre Dame Press, 2003.; KANFRANANN, P. et. al. Humiliation, degradation, debumanisation: Human dignity violated. added to the literature on human dignity with his recent 2015 book titled Human Dignity wherein he comprehensively discuss the origins of human dignity, its development through generations up to the modern day where it serves as the foundation of society ${ }^{157}$. In this section, I seek to discuss the relevance of human dignity in the AWS debate by considering first what human dignity entails and its status in international law. I then consider whether the use of autonomous weapon systems without meaningful human control is in line with human dignity.

It is important to seek to understand the content of human dignity because one of the challenges likely to be encountered when dignity is considered in the AWS debate is that there is no agreement as to what it entails ${ }^{158}$. The concept of human dignity is very old and dates back as far as 2500 years ago ${ }^{159}$. It has appeared in many disciplines and has been the subject of debate in religion, theological teachings, philosophy, history and law only to mention a few ${ }^{160}$.

After the international community witnessed historical catastrophes such as the world wars and the Holocaust, the concept of human dignity started gaining traction as a constitutional value and right ${ }^{161}$. Thus over the years, there have been what Aharon Barak calls 'the constitutionalisation of human dignity as a value or as a right. ${ }^{162}$ In the following paragraphs, I am going to discuss the concept of human dignity first as a social value that is influenced by religion and philosophy and second as a constitutional value and right.

\subsection{Human dignity as a social value}

The concept of dignity has been largely discussed and explained by theologians and philosophers. Accor-

Springer Science \& Business Media, 2011. MCCRUDDEN, C. Understanding human dignity. 2003; DUWELL, M. et al. The Cambridge handbook of human dignity. Cambridge: Cambridge University Press, 2014. 157 See BARAK, A. Human dignity. Cambridge: Cambridge University Press, 2015.

158 See DONNELLY, J. Human rights and human dignity: an analytic critique of non-western conceptions of human rights. American Political Science Review, v. 303, iss. 76, 1982. p. 132.

159 BARAK, A. Human dignity. Cambridge: Cambridge University Press, 2015. p. 17.

160 BARAK, A. Human dignity. Cambridge: Cambridge University Press, 2015. p. 17.

161 BARAK, A. Human dignity. Cambridge: Cambridge University Press, 2015. p. 17.

162 BARAK, A. Human dignity. Cambridge: Cambridge University Press, 2015. p. 17. 
ding to these groups and disciplines, the concept of dignity is understood as a social value representing positive aspects of man such as respect, glory and honour ${ }^{163}$. When theologian Thomas Aquinas discussed dignity, he perceived it as a social value that has roots in the religious dictates of a particular society ${ }^{164}$. In this sense, dignity of the human person stems from the sacred nature of his creation by a supernatural being ${ }^{165}$. The human body and soul must therefore not be transgressed on account of its sacredness; it is the image of $\operatorname{God}^{166}$. There are Christian dictates for example stating that man must respect and handle their bodies in a dignified manner because it is a temple of $\operatorname{God}^{167}$.

Courts have accepted the argument that dignity can in fact be understood from a religious or theologian point of view. The courts of Israel have referred many times to Bible verses when dealing with the issue of human dignity. For example, in the Moshe Neiman case, the court observed as follows:

\begin{abstract}
A basic element in Judaism is the idea that man was created in the image of God. (Genesis 1: 27). From this (verse one) derives certain fundamental principles regarding the value of man - equality. There is also the crowning value in human relations: 'And you shall love your neighbour as yourself.' (Leviticus 9:18). The supreme value in human relations is love of one's fellow man and the equality of man since every man was created in the image of $\operatorname{God}^{168}$.
\end{abstract}

This perception of human dignity as a social value in the religious discourse has also been supported by a number of philosophers. Philosopher Immanuel Kant described dignity as a social value that demands that each person be respected in the interest of peace and co-existence of human beings ${ }^{169}$. The difference be-

163 See CORNELL, D. Bridging the span towards justice: Laurie Ackermann and the on-going architectonic of dignity jurisprudence. Acta Juridica, v. 18, 2008.; BARAK, A. Human dignity. Cambridge: Cambridge University Press, 2015. p. 3.

164 BARAK, A. Human dignity. Cambridge: Cambridge University Press, 2015. p. 21.

165 GARRY, P. Conservatism redefined: a creed for the poor and disadvantaged. Encounter Books, 2013. p. 28.

166 BARAK, A. Human dignity. Cambridge: Cambridge University Press, 2015. p. 6.

167 See for example the Bible in 1 Corinthians 6:19 providing as follows: 'Do you not know that your bodies are temples of the Holy Spirit, who is in you, whom you have received from God? You are not your own.'

168 See EA 2/84 Moshe Neiman et al v Chairman of the Central Elections Committee for the $11^{\text {th }}$ Knesset, 8 Israel Law Reports 83, 148 (1985). 169 See MALPAS, J.; LICKISS, N. Perspectives on human dignity: a conversation. 2007. p. 95. tween human beings and animals was thus highlighted as the ability of humans to treat each other with dignity, to recognise the worth of fellow human beings ${ }^{170}$.

Likewise, as already pointed above, in pointing to the differences between humans and animals, Stoics and Cicero emphasise that it is the ability of humans to think and reason that separate them from all other creations ${ }^{171}$. In this sense, before a human engages in conduct that likely affects others; an average human being would seriously deliberate of their actions. That moment of deliberation, is the moment when homage is paid to human dignity. It may not even matter that the person may go ahead with the wrongful act; the fact that they morally know wrong from right and know when they are doing wrong is an acknowledgment of human dignity. Machines on the other hand, can never have such moral awareness. Thus the ability to think is important for the recognition of human dignity and humanity ${ }^{172}$.

Our being all alike is endowed with reason and with that superiority which lifts us above the brute. From this all morality and propriety are derived, and upon it depends the rational method of ascertaining our duty ${ }^{173}$.

Now that AWS may not have this human quality, the question is whether allowing a machine to make the decision to kill in armed conflict or in law enforcement is in line with the right to human dignity. Aharon Barak has observed that 'only humans have the ability to think and create concepts, be the subject to moral dictates and ethical responsibility. ${ }^{174}$ When making their decisions, humans take many things into consideration. This is due to the fact that humans, "not only live in the present but also in the past and in the future. ${ }^{175}$ Whether we like it or not and notwithstanding technological developments, 'only human beings constitute an ethical community of rational beings' who have the capacity to respect and preserve human dignity ${ }^{176}$.

170 See ARPPE, T. Affectivity and the social bond: transcendence, economy and violence in French social theory. 2014. p. 165.

171 See STRANGE, S. K.; ZUPKO, J. Stoicism: traditions and transformation. Cambridge: Cambridge University Press, 2004.

172 See in general I Dennis \& P Tapsfield Human abilities: their nature and measurement (2013).

173 See MT Cicero De Officis (1975)107.

174 BARAK, A. Human dignity. Cambridge: Cambridge University Press, 2015. p. 17.

175 BARAK, A. Human dignity. Cambridge: Cambridge University Press, 2015. p. 17.

176 BARAK, A. Human dignity. Cambridge: Cambridge University 
There is thus a case why meaningful human control over weapon systems must be maintained: it is only 'humans who are able to see the results of their actions, understand the connections between cause and effect, and thus control their lives. ${ }^{177}$ This is not the case with autonomous weapons systems. For this stronger reason, Peter Asaro has noted that robots cannot understand the meaning of their actions therefore making death at the hands of a robot a meaningless, undignified and arbitrary death ${ }^{178}$.

Thus, if human dignity is understood from religious teachings such as those of Judaism, Christianity, Islam, social values of togetherness like the spirit of Ubuntu or humanity, letting a machine or robot decide who lives and who dies becomes unacceptable ${ }^{179}$.

It is important to note that in the early days of discussion of the concept of human dignity, it was only understood as a social value and not a human right mainly because back then there were no constitutions to talk of ${ }^{180}$. This is not to say, however, that the theological and religious understanding of human dignity as a social value is no longer important today in particular to this AWS debate. Both the theologian and philosophical understanding of human dignity is still relevant because even the constitutional understanding of human dignity that I discuss below gives reference to the social value of human dignity - human dignity is underpinned by morals and ethics that are 'entrenched in the culture of a society. ${ }^{\text {181. }}$.

Press, 2015. p. 17.

177 BARAK, A. Human dignity. Cambridge: Cambridge University Press, 2015. p. 17.

178 ASARO, P. Jus nascendi, robotic weapons and the Martens Clause. Forthcoming, v. 14, 2015.

179 On the demands of the spirit of Ubuntu or humanity see ENGLISH, R. Ubuntu: The quest for an indigenous jurisprudence. South African Journal of Human Rights, v. 641, iss. 12, 1996.; KROEZE, I. Doing things with value: the case of Ubuntu. Stellenbosch Law Review, v. 252, n. 13, 2002.; MKOGORO, Y. Ubuntu and the law in South Africa. Buffalo Human Rights Law Review, v. 15, n. 4, 1998.

180 BARAK, A. Human dignity. Cambridge: Cambridge University Press, 2015. p. 4.

181 BARAK, A. Human dignity. Cambridge: Cambridge University Press, 2015. p. 5; See also MORRIS, B. The dignity of man. Ethics, v. 57, 1946.; EDEL, A. Humanist ethics and the meaning of human dignity. In: KURTZ, P. (Ed.). Moral problems in contemporary society: essays in humanistic ethics. Prometheus Books Publishers, 1969.; BAYEFSKY, R. Dignity, honour and human rights: Kant's perspective. Political Theory, v. 809, iss. 41, 2013.; PLATT, T. W. Human dignity and the conflict of rights. Idealistic Studies, v. 174, 1972; LICKISS, N. Human dignity and human being. In: J MALPAS, J.; LICKISS, N. (Ed.). Perspectives on human dignity: a conversation, 2007.
Of course there is a challenge in explaining dignity in terms of societal values that are influenced by different cultures, customs and belief. In this regard one commentator has observed that if human dignity is understood in terms of culture, 'human dignity in a western culture may not be the same as human dignity in a non-western culture, human dignity in one western culture may not be the same as human dignity in another western culture. ${ }^{182}$ It cannot be denied that the way one perceives human dignity is influenced by one's back ground such as culture.

Another factor that also influences one's perspective especially in relation to acceptability of certain weapons is the 'age factor' - the younger generation is inclined to accept high tech weapons even in circumstances where they may be viewed as immoral while the older generation may resist ${ }^{183}$. This was particularly the case with drones - within the military, some younger soldiers or pilots seemed readily to accept the use of armed drones while the older generation of fighters seemed to have reservations over their use ${ }^{184}$. In this sense, the content of human dignity when understood as a social value is 'contextually dependent'; it is 'a changing value in a changing world. ${ }^{185}$ Thus in view of these considerations, Barak argues that human dignity is not 'an axiomatic universal concept'; rather, 'it is a relative concept dependent upon historical, cultural, religious, social and political contexts. ${ }^{186}$.

p. 19; CARBONARI, P. C. Human dignity as a basic concept of ethics and human rights. In: GOLDWEWIJK, B. K. et. al. Dignity and human rights: the implementation of economic, social and cultural rights. Intersentia nv, 2002. p. 35.

182 BARAK, A. Human dignity. Cambridge: Cambridge University Press, 2015. p. 5; See also DONNELLY, J. Human rights and human dignity: an analytic critique of non-western conceptions of human rights. American Political Science Review, v. 303, iss. 76, 1982 ;MANGLAPUS, R. S. Human rights are not a western Discovery. World View, v. 4, n. 21, 1978; LEE, M. Y. K. Universal human dignity: some reflections in the Asian contexto. Asian Journal of Comparative Law, v. 1932, n. 3, 2008.; ANGLE, S. Human rights and Chinese thought. a cross cultural inquiry. Cambridge: Cambridge University Press, 2002.

183 See for example BERGEN, P.; ROTHENBERG, D. Drone wars. Cambridge: Cambridge University Press, 2014. p. 233.

184 BERGEN, P.; ROTHENBERG, D. Drone wars. Cambridge: Cambridge University Press, 2014. p. 233

185 BARAK, A. Human dignity. Cambridge: Cambridge University Press, 2015. p. 6.

186 BARAK, A. Human dignity. Cambridge: Cambridge University Press, 2015. p. 6; See also JONES, J. Common constitutional traditions: Can the meaning of human dignity under German law guide the European Court of Justice? Public Law, v. 167, 2004.; BOTHA, H. Human dignity in comparative perspective. Stellenbosch Law Review, v. 171, iss. 2, 2009.; WEISSTUB, D. Honour, dignity and the 
Nevertheless, even if human dignity is viewed as relative, the core of human dignity is similar across the globe. This is so because the factors that influence the content of human dignity are the same. Human dignity is shaped by rule of law, democracy and human rights. Many societies are thus built on common foundations which make the content of what is dignified and what is not more the same ${ }^{187}$. This is even more the case if human dignity is understood as a constitutional value and a right ${ }^{188}$.

The above is not to undermine the difficulties that are associated in unpacking the content of human dignity. It is surely a complex issue. However, its complexity does not mean that it is irrelevant to the AWS debate or wherever it is called for. In fact it is imperative that it be considered and given its due weight in this AWS debate. For that reason, Aharon Barak has categorically stated that 'the complexity of human dignity is not sufficient reason to justify a negative approach toward human dignity. ${ }^{, 199}$ As already indicated above, many human rights are complex but that does not warrant their abandonment. Thus in emphasising the importance of human dignity as a basis of many aspects of international law and its interpretation, Aharon Barak states as follows:

This is the case regarding human dignity: Its complexity does not make it useless. Indeed, equality, liberty and life are concepts that have been with us for centuries, whereas human dignity is a new concept in constitutional law. This novelty passes quickly; society gets accustomed to the new

framing of multiculturalists values. In: KRETZMER, D.; KLEIN, E. (Ed.). The concept of human dignity in human rights discourse. Kluwer Law International, 2002.;HOWARD, R. E. Dignity, community and human rights. In: AHMED, A. (Ed.). Human rights in cross-cultural perspectives: a quest for consensus. 1992. p. 81; LEBECH, M. What is human dignity? In: LEBECH, M. (Ed.). Maynooth philosophical papers, 2004. p. 59.

187 BARAK, A. Human dignity. Cambridge: Cambridge University Press, 2015. p. 7; See also WALDRON, J. The dignity of groups. Acta Juridica, v. 66, 2008. ; MCCRUDDEN, C. Human dignity and judicial interpretation of human rights. European Journal of International Law, v. 655, n. 19, 2008.

188 See BOGNETTI, G. The concept of human dignity: European and US constitutionalism. In: NOLTE, G. (Ed.). European and US constitutionalism. 2005. p. 85; GEWIRTH, A. Human dignity as a basis of rights. In: MEYER, M. J.; PARENT, W. A. (Ed.). The constitution of rights: human dignity and American values. Cornell University Press, 1992. p. 10; MELDEN, A. Dignity, worth, and rights. In: MEYER, M. J. et. al. The constitution of rights: human dignity and American values. Cornell University Press, 1992. p. 29.

189 BARAK, A. Human dignity. Cambridge: Cambridge University Press, 2015. p. 10. concept, with all its problems. What in the past appeared vague and unclear becomes natural and accepted, what philosophers consider to be unclear and vague is not necessarily unclear and vague to jurists. Judges do not enjoy the extent of discretion granted to theologians and philosophers. They live in a legal framework, which determines rules on whose opinion is decisive and whose is not. The judge must give meaning to human dignity in a constitution does not have the freedom of the philosopher to agree with Kant or to reject his approach. The original complexity of the concept disappears, replaced by concepts that must be implemented ${ }^{190}$.

This leads me to the next step, discussion of human dignity as a constitutional value and as right, the framework within which lawyers and judges may be confined.

\subsection{Human dignity as a constitutional value and right}

In recent years, human dignity has come to be understood not only as a social value but a protected right and of constitutional value ${ }^{191}$. Many constitutions across the globe contain the right to dignity ${ }^{192}$. In constitutions where the right to dignity is not specifically provided for in a constitution, it is implied in the constitutional value of human dignity ${ }^{193}$. In this sense, the constitutional value of human dignity is understood to be broader than the right to dignity itself $\mathrm{f}^{194}$. In most cases, constitutions provide that every person has a right to dignity and no one shall be subjected to inhuman and degrading treatment. On the basis of this right, acts or conduct that is an outrage against personal dignity is unconstitutional ${ }^{195}$. The right to dignity belongs both to the person and to the group ${ }^{196}$.

The development of the concept of dignity and its transformation to a constitutional right can be traced

190 BARAK, A. Human dignity. Cambridge: Cambridge University Press, 2015. p. 10.

191 BARAK, A. Human dignity. Cambridge: Cambridge University Press, 2015. p. 12.

192 See for example the German Constitution; BARAK, A. Human dignity. Cambridge: Cambridge University Press, 2015. p. 12.

193 BARAK, A. Human dignity. Cambridge: Cambridge University Press, 2015. p. 13.

194 BARAK, A. Human dignity. Cambridge: Cambridge University Press, 2015. p. 13.

195 WOOLMAN, S. Constitutional conversations. PULP, 2008. p. 223. 196 BARAK, A. Human dignity. Cambridge: Cambridge University Press, 2015. p. 301-303. 
back to the pre-World war era ${ }^{197}$. During and after the World Wars, the international community witnessed callous and horrendous outrages against human dignity ${ }^{198}$. Since then, many constitutions and courts - in particular those of German - started taking seriously the protection of the right to dignity ${ }^{199}$. In German, it is observed that the strong protection of the right to dignity was a response to the outrages committed by the Nazi regime during the Holocaust ${ }^{200}$. Thus in the German Constitution, the right to dignity is an absolute right ${ }^{201}$.

In the 1950s up to the 1990 s, the right to human dignity or dignity as an important part of the human rights discourse started appearing in many international human rights instruments and conventions ${ }^{202}$. It was around the same time that many African states started gaining their independence and including the right to dignity in their constitutions as many viewed colonialism and slavery as some of the worst outrages upon personal dignity committed on the continent ${ }^{203}$.

When perceived as a constitutional value, human dignity plays an important role in the human rights discourse. According to Aharon Barak, human dignity can be perceived in three ways namely: human dignity as a tool for constitutional interpretation ${ }^{204}$, human dignity as a foundation for all rights ${ }^{205}$ and human dignity as a constitutional value in the limitation of constitutional rights $^{206}$.

197 BARAK, A. Human dignity. Cambridge: Cambridge University Press, 2015. p. 49.

198 CRYER, R. et al. An introduction to international criminal law and procedure. 2014. p. 254.

199 BARAK, A. Human dignity. Cambridge: Cambridge University Press, 2015. p. 52.

200 RUBENFELD, S.; BENEDICT, S. Human subjects research after the Holocaust. 2014. p. 234.

201 BARAK, A. Human dignity. Cambridge: Cambridge University Press, 2015. p. 227.

202 See for example the European Convention on the Protection of Human Rights and Fundamental Freedoms; the ICCPR; Genocide Convention; CEDAW; CAT.

203 BARAK, A. Human dignity. Cambridge: Cambridge University Press, 2015. p. 50-64; 139; 234. In South Africa, the right to dignity occupies a unique space as the South African Constitution was drafted after the Apartheid government where black people suffered much indignity.

204 BARAK, A. Human dignity. Cambridge: Cambridge University Press, 2015. p. 105.

205 BARAK, A. Human dignity. Cambridge: Cambridge University Press, 2015. p. 104.

206 BARAK, A. Human dignity. Cambridge: Cambridge University Press, 2015. p. 112.
To start with, human dignity is an essential tool when interpreting other rights as provided in a constitution or laws that have an impact on human rights ${ }^{207}$. Now that the constitution is regarded as the supreme law of the land, the fact that human dignity is viewed as the ultimate tool of interpretation serves to highlight the importance of human dignity in our time ${ }^{208}$. When human dignity is used for purposes of constitutional interpretation, it is the interpretation that is in line with human dignity that should be adopted when interpreting human rights or other laws as it were. ${ }^{209}$ The ultimate objective of constitutions in this regard is understood to be the protection of individual persons ${ }^{210}$.

When understood as a foundation of all other rights, human dignity becomes a source of limitation to other constitutionally protected rights such as the right to life. In that sense, the argument is that all other rights are protected for the purposes of furthering the protection of human dignity ${ }^{211}$. This would mean that in circumstances where dignity clashes with other rights, it is the preservation of human dignity that takes precedence ${ }^{212}$.

The above approach was taken by the German Constitutional Court when it considered the question of whether it would be constitutional to shoot down a civilian plane that is hijacked by terrorists to save the lives of people targeted. ${ }^{213}$ In this scenario, one would assume that taking the right to life of those on board is proportional to saving the lives of those targeted yet the German Court found that such an approach is tantamount to violating the right to dignity of civilians on

207 BARAK, A. Human dignity. Cambridge: Cambridge University Press, 2015. p. 67.

208 BARAK, A. Human dignity. Cambridge: Cambridge University Press, 2015. p. 69-84.

209 BARAK, A. Human dignity. Cambridge: Cambridge University Press, 2015. p. 69.

210 See BARAK, A. Human dignity. Cambridge: Cambridge University Press, 2015. p. 98.

211 DALY, E. Dignity rights: courts, constitutions, and the worth of the human person. 2012. p. 18.

212 ALEXY, R.; RIVERS, J. A theory of constitutional rights. Oxford: Oxford University Press, 2009. p. 64.

213 The 2005 German Aviation Security Act (Luftsicherbeitsgesetv) Chapter 14 Section 3 authorised the Minister of Defense to order the shooting down of a civilian plane if the plane was being used 'against human life'. The Court found the law to be unconstitutional as it violated the right to dignity; Bundesverfassungsgericht (BVerfG - Federal Constitutional Court), 59 Neue Juristische Wochenschrift (NJW) 751 (2006); See also LEPSIUS, O. Human dignity and the downing of aircraft: the German Federal Constitutional Court strikes down a prominent anti-terrorism provision in the new Airtransport Security Act. German Law Journal, v. 761, 2006. 
board of the plane $e^{214}$.

In emphasising the right to dignity as a mother right that in certain circumstances takes precedence over other rights and legitimate concerns, the German Federal Constitutional Court observed as follows:

The hopelessness and inability to take evasive action
which marks the situation of the passenger victims
on the aircraft also extends to those who order and
carry out the shooting down of the aircraft. The
flight crew and passengers cannot evade this action
by the state due to conditions outside their control
but are helplessly at its mercy, with the consequence
that they and the aircraft will be deliberately shot
down and thus will almost certainly be killed. Such
an action ignores the status of the persons affected
as subjects endowed with dignity and inalienable
rights. By virtue of their killing being used to save
others they are treated as objects and at the same
time deprived of their rights. Given that their
lives are disposed of unilaterally by the state, the
persons on board the aircraft who, as victims, are
themselves in need of protection are denied the
valuation which is due to a human being for his or
her own sake 215 .

There are real life situations where the state can lawfully take life but out of the considerations of human dignity, life is saved. For example, there are cases where convicts have been lawfully sentenced to death but stayed on death row for too long a time that it constituted an outrage upon dignity to the extent that the state was forced to change sentence from death sentence to life imprisonment ${ }^{216}$.

When perceived as a right, human dignity has various interpretations. In some jurisdictions, it is interpreted narrowly while other jurisdictions permit wide interpretation of the right ${ }^{217}$. German courts are largely

214 Bundesverfassungsgericht (BVerfG - Federal Constitutional Court), 59 Neue Juristische Wochenschrift (NJW) 751 (2006); See also LEPSIUS, O. Human dignity and the downing of aircraft: the German Federal Constitutional Court strikes down a prominent anti-terrorism provision in the new Air-transport Security Act. German Law Journal, v. 761, 2006.

215 Bundesverfassungsgericht (BVerfG - Federal Constitutional Court), 59 Neue Juristische Wochenschrift (NJW) 751 (2006); See also LEPSIUS, O. Human dignity and the downing of aircraft: the German Federal Constitutional Court strikes down a prominent anti-terrorism provision in the new Air-transport Security Act. German Law Journal, v. 761, 2006.

216 MCKENZIE v Jamaica, Case 12.023, Inter-American Commission on Human Rights, Report Number 41/00, OEA/Ser.L/V/ II.106 doc.3 (2000). See also NOVAK, R. The global decline of the mandatory death penalty: constitutional jurisprudence and legislative reform in Africa, Asia, and the Caribbean. Ashgate Publishing, 2014. p. 62.

217 BARAK, A. Human dignity. Cambridge: Cambridge University credited for developing and mapping out the content of the right to dignity ${ }^{218}$. As already mentioned above, in terms of the German Basic Law, the right to dignity is considered an absolute right that cannot be subject to any limitation and any limitation by any means is considered unconstitutional ${ }^{219}$. The right to dignity is seen to be violated whenever 'a person is seen as a mere means for fulfilling someone's ends. ${ }^{220}$.

Aharon Barak has emphasised that the right to dignity is an important right, it is 'a framework right and a mother right', and all the other rights are 'daughter rights that gather together under its wings. ${ }^{221}$ The right to dignity is also considered a gap-filler, where there are no specific provisions providing for lawful treatment of persons, the right to dignity serves as a fall back ${ }^{222}$. Examples of human rights that are considered to be 'daughter rights' under the wings of dignity are the right to personality, dignified human existence and subsistence, reputation, family life, equality, freedom of expression, freedom of conscience and due process.

If due process is part of the daughter rights under human dignity, the question becomes whether allowing a machine to assess the need to use lethal or any force against a human being is in line with the demands of due process. Use of computers to decide the guilty or otherwise of accused persons in court has long been rejected $^{223}$. By the same token, the use of an algorithm to decide whether a person lives or dies may as well be condemned.

As already noted above, a question may arise as to the correctness or efficacy of relying on the right to dignity in the AWS debate. This is mainly because many scholars argue that the right to dignity is not only fluid and flexible but vague ${ }^{224}$. On account of its flexibility and lack of precise definition, commentators may

Press, 2015. p. 20.

218 DALY, E. Dignity rights: courts, constitutions, and the worth of the human person. 2012. p. 178.

219 See Section 1(1) of Grundgesetr; See also BARAK, A. Human dignity. Cambridge: Cambridge University Press, 2015. p. 20.

220 BARAK, A. Human dignity. Cambridge: Cambridge University Press, 2015. p. 20.

221 BARAK, A. Human dignity. Cambridge: Cambridge University Press, 2015. p. 156; 160; 252.

222 BARAK, A. Human dignity. Cambridge: Cambridge University Press, 2015. p. 21.

223 GERSTING, J. L.; GEMIGNANI, M. C. The computer: history, workings, uses \& limitations. Ardsley House, 1988. p. 270.

224 BARAK, A. Human dignity. Cambridge: Cambridge University Press, 2015. p. 21. 
argue that the right to dignity gives judges too much power and discretion which is subject to abuse. More so, whoever wants to use the right to dignity may interpret it in a way that fits or support their argument. For that reason, the right to dignity has been perceived as a 'conversation stopper.'225.

However, it can be observed that the right to dignity is not the only right that is broad and vague. Other human rights such as the right to liberty and equality are equally broad if not vague yet this does not stop commentators and judges from relying on them. If anything, judges have experience and are accustomed to interpreting these rights as they are armed with many interpretation aids and tools. In this sense and with particular reference to the right to dignity, Aharon Barak has argued that 'what appears to the theologian and the philosopher as a limitless right appears to the judge as a right that is hemmed in the rules of interpretation. ${ }^{226}$ The essence of the argument is that the right to dignity is not incapable of meaning.

Aharon Barak has suggested three ways by which one can give content to the right to dignity: determining the content of human dignity through theological models, determination of the content through philosophical models and the constitutional models ${ }^{227}$. If all these models are considered, the idea of what is dignified and what is not, becomes clear. I have already given examples of Judaism, Christianity and Islam as religions that give content to human dignity. The human person is special, sacred and a living image of God and deserves the utmost respect ${ }^{228}$. To violate the dignity of the human person in this sense is to transgress against God himself ${ }^{229}$. When a human being is viewed as an end, respect continues even after the soul departs from the body, that is why acts that are outrages upon personal dignity can be committed even on a dead body ${ }^{230}$. It is for those reasons that there are laws in many jurisdictions giving relatives of condemned persons the right to

225 BARILAN, Y. M. Human dignity, human rights, and responsibility: the new language of global bioethics and biolaw. 2012. p. 2.

226 BARAK, A. Human dignity. Cambridge: Cambridge University Press, 2015. p. 21.

227 BARAK, A. Human dignity. Cambridge: Cambridge University Press, 2015. p. $114-120$.

228 BARAK, A. Human dignity. Cambridge: Cambridge University Press, 2015. p. 114.

229 BARAK, A. Human dignity. Cambridge: Cambridge University Press, 2015. p. 114.

230 See Practice relating to Rule 113 of ICRC Customary international humanitarian law on the treatment of the dead. accord their relative a proper burial.

As already highlighted above, for dignity to be preserved, force must only be used against a person by a human being since it is the human alone who is capable of reasoning. This is the position of scholars such as Dworkin, Margalit, Statman and Kant only to mention a few. ${ }^{231}$ Thus before taking someone's life or using force against them - even legitimately so - there should be deliberation by a human being, assessment and evaluation of the reasons thereof ${ }^{232}$. As I will discuss in Chapter 6, the content of human dignity is intrinsically linked to the notion of humanity. When viewed from the standpoint of humanity, dignity is where a person is seen as a human being, a being with 'autonomy of will'; in this sense 'humanity of the person is seen as the rejection of viewing a person as a mere means. ${ }^{233}$ Something important is seen in every human being, something that deserves respect ${ }^{234}$.

\subsection{Are AWS in line with human dignity?}

Having discussed the notion of ubuntu or humanity by considering the role it has played in Africa and international, also how the concept is also based on the need to preserve human dignity, I emphasise that to allow AWS 'the power to kill seems a bit too much like setting a mousetrap for human beings; to do so would be to treat our enemies like vermin. ${ }^{235}$ The vivid mouse-analogy is fully expressed by Aaron Johnson who cites the fundamental right to dignity in objecting the idea of delegating the decision to kill to AWS.

A mouse can be caught in a mouse-trap, but a human
must be treated with more dignity. A mouse-trap kills
targets with certain characteristics based on certain
behaviour, i.e. anything of sufficient mass eating or,
at least, touching the bait. The trigger is designed to
attack based on the mouse-trap's perception of the
target and its actions. The complexity of the trigger
is not what we are concerned with - a mouse can

231 BARAK, A. Human dignity. Cambridge: Cambridge University Press, 2015. p. $116-119$.

232 BARAK, A. Human dignity. Cambridge: Cambridge University Press, 2015. p. $116-119$.

233 See BARAK, A. Human dignity. Cambridge: Cambridge University Press, 2015. p. 130.

234 See BARAK, A. Human dignity. Cambridge: Cambridge University Press, 2015. p. 130.

235 SPARROW, R. Robotic weapons and the future of war. In: WOLFENDALE, J.; TRIPODI, P. (Ed.). New wars and new soldiers: military ethics in the contemporary world. Ashgate Publishing, 2011. p. 11. 
be killed by a machine, as it has no inherent dignity. A robot is in a way like a high tech mouse-trap, it is not a soldier with concerns about human dignity or military honour. Therefore, a human should not be killed by a machine as it would be a violation of our inherent dignity ${ }^{236}$.

In furthering the dignity argument, Jay Strawser states that 'the user [of AWS] fails to express his own dignity likely because he fails to respect the victims' dignity ${ }^{237}$, 'the idea that in turning these decisions over to machines, human persons fail to satisfy reflexive duties to respect their own rationality, autonomy or dignity, they fail to take responsibility for their own actions. ${ }^{238}$.

Heyns echoes the same sentiments as he states that giving robots the power to decide who to kill paints an image of 'AWS as some kind of mechanized pesticide.'239 To that end and notwithstanding whether robots can do better than humans, Heyns argues that the overriding consideration may be whether it is acceptable to let machines decide whom to kill. If it is unacceptable, then 'no other consideration can justify deployment of AWS no matter the level of technical competence at which they operate. ${ }^{240}$.

Further, Heyns succinctly summarises the impact and undesirability of taking humans out of the loop in the use of lethal force: now that AWS lack morality and mortality"241, 'taking humans out of the loop risks taking humanity out of the loop. ${ }^{.242}$ Given that humans not only have the capacity to adhere to the minimum set standard 'but they also hold the potential to adhere to higher values' unlike AWS 'which lack the capacity to rise above minimum standards', giving robots the power to make decisions on who to kill leads to 'a vacuum of

236 JOHNSON. A. M. The morality of autonomous robots. Journal of Military Ethics, v. 134, 2013.

237 STRAWSER, J. Killing by remote control: the ethics of an unmanned military. Oxford: Oxford University Press, 2013. p. 239.

238 STRAWSER, J. Killing by remote control: the ethics of an unmanned military. Oxford: Oxford University Press, 2013. p. 237.

239 A/HRC/23/47, Report of the Special Rapporteur on extrajudicial, summary or arbitrary executions, Christof Heyns, 9 April 2013, p 18 para 95.

240 A/HRC/23/47, Report of the Special Rapporteur on extrajudicial, summary or arbitrary executions, Christof Heyns, 9 April 2013p 17 para 93.

241 A/HRC/23/47, Report of the Special Rapporteur on extrajudicial, summary or arbitrary executions, Christof Heyns, 9 April 2013, p 17 para 94.

242 A/HRC/23/47, Report of the Special Rapporteur on extrajudicial, summary or arbitrary executions, Christof Heyns, 9 April 2013, p 16 para 89. moral responsibility ${ }^{243}$ which is tantamount to 'giving up on hope for a better world. ${ }^{244}$ To that end, Heyns postulates that allowing a machine to make a decision to take life may be 'inherently arbitrary and all resulting deaths [constituting] arbitrary deprivations of life. ${ }^{245}$.

Ron Arkin reflects that if taking a human out of the loop is the crux of the matter, then one question needs to be answered; 'what level is the human in the loop? ${ }^{246} \mathrm{He}$ argues that several military robotics such as the Phalanx system for Aegis-class cruisers and the South Korean robot platform mentioned in Chapter 1 already operate with very limited human supervision $^{247}$. In an attempt to answer that question, Arkin seems to contradict the proposed definition of AWS, a definition which points to the important aspect of the decision to kill being made by a machine without human intervention. A close reading of most of Arkin's works suggests that in as much as AWS may have the capability to make the decision to kill, that decision will be monitored and supervised by the human operator. The issue, however, which has brought much concern is not whether it is possible for a human operator to supervisor AWS. The concern is of creating machines which, albeit the possibility of human supervision, have the capability to make a decision to kill and execute it without a human intervention or contribution to that decision. The international community, arguably, cannot take solace in the mere fact that it is technically possible for a human to monitor, a possibility which may dwindle to nothing once AWS become available and are deployed.

243 A/HRC/23/47, Report of the Special Rapporteur on extrajudicial, summary or arbitrary executions, Christof Heyns, 9 April 2013, p 17 para 93.

244 A/HRC/23/47, Report of the Special Rapporteur on extrajudicial, summary or arbitrary executions, Christof Heyns, 9 April 2013, p 18 para 97.

245 A/HRC/23/47, Report of the Special Rapporteur on extrajudicial, summary or arbitrary executions, Christof Heyns, 9 April 2013, p 17 para 90.

246 ARKIN, R. Governing Lethal Behavior: embedding ethics. Hybrid Deliberative Reactive Robot Architecture. Technical Report GIT-GVU-07-11. Available at: <http://www.cc.gatech.edu/ai/ robot-lab/online-publications/formalizationv35.pdf>. p 4.

247 ARKIN, R. Governing lethal behaviour: embedding ethics in a hybrid deliberative/reactive robot architecture. Technical Report GIT-GVU, 2011. 


\section{Conclusions}

In conclusion, it is noted that the African notion of ubuntu or humanity is relevant to the AWS debate. Of course, they may be scholars who argue that notions of humanity and dignity are incapable of meaning or that there are too vague to be relied on hence their irrelevance. However, as I have discussed in this paper, these ter$\mathrm{ms}$ are capable of meaning and have since been relied upon before in the formulation of laws and policies. I also emphasise that in this on-going debate on AWS, African states should more fully participate, not only because they may be affected by this kind of technology in the future but because African perspective on the notion of humanity or ubuntu should be heard in this debate. As regard how AWS without meaningful human control impact on the notion of ubuntu or humanity, I conclude that they are inconsistent with this notion and their use will violate the important right to dignity. This means that even if AWS were to be technically capable of using force against legitimate targets, it may still amount to an affront to human dignity since only humans must make the decision on the use of force.

\section{References}

A/68/382. Report of the Special Rapporteur on extrajudicial, summary or arbitrary executions, Christof Heyns, 13 September 2013.

AARONSON, M. Precision strike warfare and international intervention: strategic, ethico-legal and decisional implications. Abingdon: Routledge, 2014.

ABASS, A. Protecting buman security in Africa. Oxford: Oxford University Press, 2010.

ABASS, A. Proving State responsibility for genocide: the ICJ in Bosnia v Serbia and the International Commission of Inquiry for Darfur. Fordham International law Journal, v. 31, iss. 4, 2008.

ABI-SAAB, G. The specificities of humanitarian law'. In: AWINARSKI, C. (Ed.). Studies and essays on international bumanitarian law and the Red Cross principles. Martinus Nijhoff, 1984.

ADAMS, C. A moment of peace amid Ferguson anger: cop hugs emotional protester after befriending him during march, 2014. Available at: <http://www.dailymail.
co.uk/news/article-2853823/The-hug-shared-round-world-touching-moment-cop-hugs-emotional-Ferguson-protester-gesture-peace.html>.

ADAMS, T. K. Future warfare and the decline of human decision making, parameters. United States Army War College Quarterly, p. 57-58, 2001

AFFLERBACH, H.; STRACHAN, H. How fighting ends: a history of surrender. Oxford: Oxford University Press, 2012.

ALEXY, R.; RIVERS, J. A theory of constitutional rights. Oxford: Oxford University Press, 2009.

ALLEY, R. M. Internal conflict and the international community: wars without end? Farnham: Ashgate, 2004.

ALMEIDA de Quinteros et al v Uruguay. 15 October 1982. CCPR/C/OP/2 paras 14, 16.

ALSTON, P. The CIA and targeted killings beyond boarders. Harvard National Security Journal, v. 2, 2011.

ALSTON, P.; SHAMSI, H. A killer above the law. Available at: <http://www.guardian.co.uk/profile/philip-alston>.

ALVAREZ, J. E. Alternatives to international criminal justice. The Oxford Companion to International Criminal Justice, v. 33, 2009.

ALVAREZ, J. E. Alternatives to international criminal justice. In: CASSESE, A. (Ed.). The Oxford companion to international criminal justice. Oxford: Oxford University Press, 2009.

AMNESTY International United States of America targeted killing policies violate right to life, 2012. Available at:<http://www.amnesty.org/en/library/info/ AMR51/047/2012/en>.

ANDERSON, K.; WAXMAN, M. Law and ethics for autonomous weapon systems: why a ban won't work and how the laws of war can. American University $W a$ shington College of Law Research Paper, v. 3, 2013.

ANDERSON, K.; WAXMAN, M. Law and ethics for robot soldiers. American University WCL Research, v.32, iss. 18, 2012.

ANDERSON, K.; WAXMAN, M. Law and ethics for robot soldiers. Policy Review, v. 13, n. 176, 2012. Available at: <http://www.hoover.org/publications/policy-review/article/135336>.

ANGLE, S. Human rights and Chinese thought. a cross cul- 
tural inquiry. Cambridge: Cambridge University Press, 2002.

ANNAN, K. Address to the UN Security Council meeting on counterterrorism measures, 2002. Available at: <http://www.unis.unvienna.org/unis/pressrels/2002/ sgsm8105.html>.

ARAI, Y. The law of occupation: continuity and change of international humanitarian law, and its interaction with international human rights law. BRILL, 2009.

ARAJÄRVI, N. The changing nature of customary international law: methods of interpreting the concept of custom in international criminal tribunals. Abingdon: Routledge, 2014.

ARKIN, R. C. Lethal autonomous systems and the plight of the non-combatant. Ethics and Armed Forces, v. 9, 2014.

ARKIN, R. et al. Moral decision-making in autonomous systems: enforcement, moral emotions, dignity, trust and deception, 2011. Available at: <https:// smartech.gatech.edu/bitstream/handle/1853/40769/ IEEE-ethicsv17.pdf?sequence $=1>$.

ARKIN, R. Governing Lethal Behavior. embedding ethics. Hybrid Deliberative Reactive Robot Architecture. Technical Report GIT-GVU-07-11. Available at: <http:/ / www.cc.gatech.edu/ai/robot-lab/online-publications/ formalizationv35.pdf>.

ARKIN, R. Governing lethal behaviour in autonomous robots. CRC Press, 2009.

ARKIN, R. Governing lethal behaviour in autonomous robots. International Committee of the Red Cross Press, v. 127, 2009.

ARKIN, R. Governing lethal behaviour: embedding ethics in a hybrid deliberative/reactive robot architecture. Technical Report GIT-GVU, 2011.

ARKIN, R. Lethal Autonomous weapon systems and the plight of the non combatant. 2014. Available at: <http://www. unog.ch/80256EDD006B8954/\%28httpAssets\%29/ FD01CB0025020DDFC1257CD70060EA38/\$file/ Arkin_LAWS_technical_2014.pdf>.

ARKIN, R. The Robot didn't do it'. Anticipatory Ethics, Responsibility and Artificial Agents, v. 1, 2013.

ARKIN'S presentation at the CCW expert meeting on lethal autonomous weapon systems. Available at: <http://www.unog.ch/80256EDD006B8954/\%28htt
pAssets\%29/FD01CB0025020DDFC1257CD70060E A38/\$file/Arkin_LAWS_technical_2014.pdf>.

ARPPE, T. Affectivity and the social bond: transcendence, economy and violence in French social theory. Ashgate Publishing, 2014.

ARTICLE 36 Key areas for debate on Autonomous Weapon Systems, 2014. Available at: <http://www.article36.org/wp-content/uploads/2014/05/A36-CCW-May-2014.pdf>.

ARTICLE 36 statement by Laura Boillot to CCW informal meeting on lethal Autonomous Weapon Systems. Available at: <http://www.article36.org/statements/ remarks-to-the-ccw-on-autonomous-weapons-systems-13-may-2014/>.

ASARO, P. How just could a robot war be? In: BREY P. et. al. (Ed.). Current issues in computing and philosophy. IOS Press, 2008.

ASARO, P. Jus nascendi, robotic weapons and the Martens Clause. Forthcoming, v. 14, 2015.

ASARO, P. On banning autonomous weapon systems: human rights, automation, and the dehumanisation of lethal decision-making. International Review of the Red Cross, v. 11, iss. 94, 2012.

ASARO, P. Presentation to the CCW meeting, 2014. Available at: <http://www.unog.ch/80256EDD006B 8954/\%28httpAssets\%29/79F6199F74DC824CC12 57CD8005DC92F/\$file/Asaro_LAWS_ethical_2014. pdf $>$.

ASIMOV, I.; Shulman, J. A. Isaac Asimov's book of science and nature quotations. Weidenfeld \& Nicolson, 1998.

AVENA and other Mexican Nationals (Mexico v United States of America). Judgment of 31 March 2004, paras 131, 138 and the La Grand Case (German v the United States of America). Judgment of 27 June 2001, ICJ Reports 2001 p514 para 125.

BABIKER, M. A. Application of international humanitarian and human rights law to the armed conflicts of the Sudan: complementary or mutually exclusive regimes? Intersentia, 2007.

BADAR, M. E. The concept of mens rea in international criminal law: the case for a unified approach. 2013.

BALITZKI, A. The Martens Clause: origin of new source of international law. 2009. Available at http:// 
www.grin.com/en/e-book/133806/the-martens-clause

BANKS, W. C. New battlefields/old laws: critical debates on asymmetric warfare. Columbia: Columbia University Press, 2013.

BARAK, A. Human dignity. Cambridge: Cambridge University Press, 2015.

BARBER, R. J. The proportionality equation: balancing military objectives with civilian lives in the armed conflict in Afghanistan. Journal of Conflict and Security Law, v. 467, iss. 15, 2010.

BARBOERAM-ADHIN and Others v Suriname Communication Number $146 / 1983$ and 148 to $154 / 1983$ UN Doc Supp No 40 (A/40/40) at 187, 1985 14.3.

BARILAN, Y. M. Human dignity, human rights, and responsibility: the new language of global bioethics and biolaw. MIT Press, 2012.

BARNIDGE, R. P. A qualified defense of American drone attacks in Northwest Pakistan under international humanitarian law. Boston University International Law Journal, 2012.

BARTOLINI, G. The civilianization of the contemporary armed conflicts. Select Proceedings of the European Society of International law, v. 569, iss. 2, 2008.

BASHI, S.; MANN, K. Disengaged occupiers: the legal status of Gaza: gisha, legal center for freedom of movement, 2007.

BASIC Principles and Guidelines on the Right to a Remedy and Reparation for Victims of Gross Violations of International Human Rights Law and Serious Violations of International Humanitarian Law, adopted by the UN GA in 2006.

BASSIOUNI, M. C. Crimes against humanity: historical evolution and contemporary application. Cambridge: University Press, 2011.

BAYEFSKY, R. Dignity, honour and human rights: Kant's perspective. Political Theory, v. 809, iss. 41, 2013.

BEERS, B. et al. Humanity across international law and biolaw. Cambridge: Cambridge University Press, 2014.

BELLAMY, A. J. The responsibility to protect: a defence. Oxford: Oxford University Press, 2014.

BENJAMIN, M. Drone warfare: killing by remote control. Verso Books, 2013.

BERGEN, P.; ROTHENBERG, D. Drone wars. Cam- bridge: Cambridge University Press, 2014.

BERIĆ and Others v Bosnia and Herzegovina, application n. 36357/04 et al 2007.

BESWICK, D.; JACKSON, P. Conflict, security and development: an introduction: Routledge, 2014.

BIANCHI, A. State responsibility and criminal liability of individuals. In: CASSESE, A. (Ed.). The Oxford companion to international criminal justice: Oxford: Oxford University Press, 2009.

BIANCHI, A.; PETERS, A. Transparency in international law. Cambridge: Cambridge University Press, 2013.

BIERI, M.; DICKOW, M. Lethal 'Autonomous Weapon Systems: future challenges. Center for Security Studies, Analysis in Security Policy, v. 3, 2014. Available at: <http:/ / www.css.ethz.ch/publications/pdfs/CSSAnalyse164-EN.pdf>.

BIONTINO, M. On behalf of the foreign office of Republic of Germany to the CCW expert meeting lethal autonomous weapon systems. Available at: <http://www.unog.ch/80256E DD006B8954/\%28httpAssets\%29/6035B96DE2BE0 C59C1257CDA00553F03/\$file/Germany_LAWS_Technical_Summary_2014.pdf>.

BLAKE, D.; IMBURGIA, J. S. Bloodless weapons? the need to conduct legal reviews of certain capabilities and the implications of defining them as weapons. Air Force Law Review, v. 163, iss. 66, 2010.

BLONDEL, J. L. The meaning of the word 'humanitarian' in relation to the fundamental principles of the Red Cross and Red Crescent. International Review of the Red Cross, v. 273, p. 507-515, 1989.

BOGASKI, G. American protestants and the debate over the Vietnam War: evil was loose in the world. Lexington Books, 2014.

BOGNETTI, G. The concept of human dignity: European and US constitutionalism. In: NOLTE, G. (Ed.). European and US constitutionalism: Cambridge: Cambridge University Press, 2005.

BOHOSLAVSKY, J. P.; CERNIC, J. L. Making sovereign financing and buman rights work. Bloomsbury Publishing, 2014.

BONAFE, B. I. The relationship between state and individual responsibility for international crimes. BRILL, 2009.

BOOGARD, J. C. Fighting by the principles: principles 
as a source of international humanitarian law. In: MATTHEE, M. et. al. (Ed.). Armed conflict and international bumanitarian law: in search for the human face. Springer Science \& Business Media, 2013.

BOON, K. et al. The drone wars of the 21st century: costs and benefits. Oxford: Oxford University Press, 2014.

BOOTHBY, B. And for such time as: the time dimension to direct participation in hostilities. NYU Journal of International Law and Policy, v. 758, iss. 42, 2010.

BOOTHBY, H. W. Weapons and the law of armed conflict. Oxford: Oxford University Press, 2009.

BOOTHBY, W. H. Conflict law: the influence of new weapons technology, human rights and emerging actors: Springer, 2014.

BOSNIA and Herzegovina $v$ Serbia and Montenegro (2007). Case concerning the Application of the Convention on the Prevention and Punishment of the Crime of Genocide.

BOTHA, H. Human dignity in comparative perspective. Stellenbosch Law Review, v. 171, iss. 2, 2009.

BOUCHET-SAULNIER, F. The practical guide to humanitarian law. Rowman \& Littlefield Publishers, 2013.

BREHMER, B. The dynamic OODA loop: amalgamating Boyd's OODA and the cybernetic approach to command and control. Swedish National Defence College, v. 2, 2005.

BRENNER-BECK, D. et al. The war on terror and the laws of war. a military perspective. Oxford: Oxford University Press, 2015.

BROLLOWSKI, H. Military robots and the principle of humanity. In: MATTHEE, M. et. al. (Ed.). Armed confict and international humanitarian law: in search for the buman face. Springer Science \& Business Media, 2013.

BRZOSKA, M. Putting teeth in the tiger: improving the effectiveness of arms embargoes. Emerald Group Publishing, 2009.

BUNNELL, T. et al. Cleavage, connection and conflict in rural, urban and contemporary Asia. Springer Science \& Business Media, 2012.

BURKE, M.; PERSI, Vicentic L. Remedies and Reparations. In: CASEY-MASLEN, S. (Ed.). Weapons under international buman rights law. Cambridge: Cambridge University Press, 2014.
CALI, B. International law for international relations. Oxford: Oxford University Press, 2010.

CAMERON, I. National security and the European Convention on Human Rights. Martinus Nijhoff Publishers, 2000.

CAMPAIGN to Stop killer robots statement by mary wareham. Human Rights watch to the convention on conventional weapons meeting of experts. Geneva, Switzerland, 2014. Available at: http://www.unog.ch/80256EDD006B89 54/\%28httpAssets\%29/16B608BD428C6D17C1257C DA0056AA62/\$file/NGO+Campaign+StopKillBots_ FinalStatement.pdf

CARACAZO V Venezuela (Reparation). Judgement of 29 August 2002, Series C No 95, para 115.

CARBONARI, P. C. Human dignity as a basic concept of ethics and human rights. In: GOLDWEWIJK, B. K. et. al. Dignity and human rights: the implementation of economic, social and cultural rights. Intersentia nv, 2002.

CARMEN, R. V.; $\square$ WALKER, J. T. Briefs of leading cases in law enforcement. Routledge, 2014.

CARNAHAN, B. M. Unnecessary suffering, the Red Cross and tactical laser weapons. Loyola International \& Comparative Law Review, v. 73, iss. 18, 1996.

CARPENTER, C. How scared are people of 'killer robots' and why does it matter? 2013. Available at: <https://www. opendemocracy.net/charli-carpenter/how-scared-are-people-of- $\%$ E $2 \% 80 \% 9$ Ckiller-robots $\%$ E2 $\% 80 \% 9 D$ -and-why-does-it-matter>.

CARR, N. The glass cage: where automation is taking us. Random House, 2015.

CARROLL, M.; ROSSON, M. B. Paradox of the Active User. In: CARROLL, J. M. (Ed.). Interfacing thought: cognitive aspects of human-computer interaction. Mit Press, 1987.

CASEY-MASLEN, S. The war report: armed conflict in 2013. Oxford: Oxford University Press, 2014.

CASSESE, A. The buman dimension of international law: selected papers of Antonio Cassese. Oxford: Oxford University Press, 2008.

CASSESE, A. The Martens Clause: Half a loaf or simply pie in the sky? European Journal of International Law, v. $187,2000$.

CASSESE, A. The Nicaragua and Tadic tests revisited 
in light of the ICJ Judgment on genocide in Bosnia. European Journal of International Law, v. 653, iss. 18, 2007.

CERETTI, A. Collective violence and international crimes. In: CASSESE, A. (Ed.). The Oxford companion to international criminal justice. Oxford: Oxford University Press, 2009.

CHAIRMAN'S Report of the 2014 informal meeting of experts on lethal autonomous weapon systems (LAWS). Available at: <http://www.unog.ch/8 0256EDD006B8954/\%28httpAssets\%29/350D9A BED1AFA515C1257CF30047A8C7/\$file/Report_ AdvancedVersion_10June.pdf $>$.

CHANDLER, D.; HYNEK, N. Critical perspectives on buman security: rethinking emancipation and power in international relations. Routledge, 2010.

CHARLES, J. D. Retrieving the natural law: a return to moral first things. Wm. B. Eerdmans Publishing, 2008.

CHENWI, L. M. Towards the abolition of the death penalty in Africa: a human rights perspective. PULP, 2011.

CHESNEY, R. Who may be killed? Anwar Al-Awlaki as a case study in the international legal regulation of lethal force. Yearbook of International Humanitarian Law, v. 26, 2011.

CHONGWE v Zambia, Communication Number 821/1998, Views adopted on 25 October 2000. Delgado Paezv Columbia UN Doc. Number 40 (A/45/40), Vol II, Annex IX, Sect D, Communication 195/1985, 12 July 1990.

CHRISTENSEN, E. The dilemma of direct participation in hostilities. Journal of Transnational Law and Policy, v. 281 , iss. $19,2010$.

CLAPHAM, A.; GAETA, P. The oxford handbook of international law in armed conflict. Oxford: Oxford University Press, 2014.

CLARK, O. G. Mind and autonomy in engineered bio-systems. Engineering Applications of Artificial Intelligence, v. $12,1999$.

COLE, G. et al. Criminal justice in America. Cengage Learning, 2015.

COLLINS, A. Shielded from justice: police brutality and accountability in the United States. Human Rights Watch, 1998.

COLUMBIA LAW SCHOOL HUMAN RIGHTS
INSTITUTE. Targeting operations with drone technology: Humanitarian law implications. Available at: <http://www. law.columbia.edu/ipimages/Human_Rights_Institute/ BackgroundNoteASILColumbia.pdf $>$.

COMMISSION on the Responsibility of Authors of War and on Enforcement of Penalties 1919 Report. American Journal of International Law, v. 25, 1920.

CONDÄ, H. V. A handbook of international human rights terminology. U of Nebraska Press, 2004.

COOK, M. The moral warrior. ethics and service in the US military. SUNY Press, 2004.

COPPIN, G.; LEGRAS, F. Autonomy spectrum and performance perception issues in swarm supervisory control. Proceedings of the IEEE, v. 12, p. 590-2, 2012.

CORAM, R. Boyd: the fighter pilot who changed the art of war. Little, Brown and Company, 2002.

CORN, G. S. et al. Belligerent targeting and the invalidity of a least harmful means rule. Maroon Ebooks, 2015.

CORNELL, D. Bridging the span towards justice: Laurie Ackermann and the on-going architectonic of dignity jurisprudence. Acta Juridica, v. 18, 2008.

COUPLAND, R. Humanity: what is it and how does it influence international law? International Review of the Red Cross, v. 969, 2001.

COUPLAND, R. M. Towards a determination of which weapons cause superfluous injury or unnecessary suffering. The SIrUS Project, ICRC, v. 7, 1997.

COUPLAND, R.; LOYE, D. The 1899 Hague Declaration concerning expanding bullets: a treaty effective for more than 100 years faces complex contemporary issues. International Review of the Red Cross, v. 135, iss. 849, 2003.

Crawford, E. The treatment of combatants and insurgents under the law of armed conflict. Oxford: Oxford University Press, 2010.

CRAWSHAW, R. Human rights and policing. Martinus Nijhoff Publishers, 2007.

CRAWSHAW, R. Police and buman rights: a manual for teachers and resource persons and for participants in human rights programmes. BRILL, 2009.

CROWE, J.; $\square$ WESTON-SCHEUBER, K. Principles of international humanitarian law. Edward Elgar Publishing, 2013. 
CRUFT, R. et al. Philosophical foundations of human rights. Oxford: Oxford University Press, 2014.

CRYER, $\mathrm{R}$ et al. An introduction to international criminal law and procedure. Cambridge: Cambridge University Press, 2014.

DALY, E. Dignity rights: courts, constitutions, and the worth of the human person. 2012.

DAVID, R. Victims on transitional justice. Human Rights Quarterly v. 393, iss. 27, 2005.

DE GUZMAN, M. et al. Strategic responses to crime: thinking locally, acting globally. CRC Press, 2011.

DE WET, E. The international constitutional order. International and Comparative Law Quarterly, v. 51, iss. 55, 2006.

DEHN, J. C.; HELLER, K. Targeted killing: the case of Anwar Al-Aulaqi. University of Pennsylvania Law Review, $v$. 159, p. 90-191, 2011.

DENNIS, I.; TAPSFIELD, P. Human abilities: their nature and measurement. Psychology Press, 2013.

DINNISS, H. H. Cyber warfare and the laws of war. Cambridge: Cambridge University Press, 2012.

DINSTEIN, Y. Non-international armed conflicts in international law. Cambridge: Cambridge University Press, 2014.

DINSTEIN, Y. Terrorism as an international crime. Israel Yearbook of Human Rights, v. 63, iss. 55, 1987.

DINSTEIN, Y. The defence of 'obedience to superior orders' in international law. Oxford: Oxford University Press, 2012.

DOARE, $\mathrm{R}$ et al. Robots on the battlefield: contemporary issues and implications for the future. Maroon Ebooks, 2014.

DONELLY, J. International human rights boulder. Westview Press, 2013.

DONNELLY, J. Human rights and human dignity: an analytic critique of non-western conceptions of human rights. American Political Science Review, v. 303, iss. 76, 1982 .

DORIA, J. et al. The Legal regime of the International Criminal Court. essays in honour of professor Igor Blishchenko [1930-2000]: BRILL, 2009.

DÖRMANN, K. Elements of war crimes under the Rome Statute of the International Criminal Court. sources and commentary. Cambridge: Cambridge University Press, 2003.

DÖRMANN, K. The legal situation of unlawful/unprivileged combatants. International Law Review of the Red Cross, v. 46, iss. 85, 2002.

DOSWALD-BECK, L. Human rights in times of conflict and terrorismo. Oxford: Oxford University Press, 2011.

DUFFY, H. The 'war on terror' and the framework of international law. Cambridge: Cambridge University Press, 2015.

DUNANT, J. H. A memory of Solferino: international committee of the red cross. 2006.

DUWELL, M. et al. The Cambridge handbook of human dignity. Cambridge: Cambridge University Press, 2014.

DWORKIN, G. The theory and practice of autonomy. Cambridge: Cambridge University Press, 1988.

E/CN.4/1992/26. Report of the United Nations Special Rapporteur on the situation of human rights in $\mathrm{Ku}-$ wait under Iraq occupation, Walter Kälin, 1992.

EBERLE, E. J. Dignity and liberty: constitutional visions in Germany and the United States. Praeger, 2002.

EDEL, A. Humanist ethics and the meaning of human dignity. In: KURTZ, P. (Ed.). Moral problems in contemporary society: essays in humanistic ethics. Prometheus Books Publishers, 1969.

EDMUND, C. Sherman: merchant of terror, advocate of Peace. Pelican Publishing, 1992.

ENGELAND, A. Civilian or combatant? a challenge for the twenty-first century. Oxford: Oxford University Press, 2011.

ENGLISH, J. A. Surrender invites death: fighting the waffen SS in Normandy. Stackpole Books, 2014.

ENGLISH, R. Ubuntu: The quest for an indigenous jurisprudence. South African Journal of Human Rights, v. 641, iss. 12, 1996.

ERIN, C. A.; $\square$ OST, S. The criminal justice system and health care. Oxford: Oxford University Press, 2007.

ESCORIHUELA, A. L. Humanitarian law and human rights law: the politics of distinction. Michigan State Journal of International Law, v. 299, iss. 19, 2011.

EVANGELISTA, M. Law, ethics, and the war on terror. John Wiley \& Sons, 2013. 
EVANS, T. D. Note at war with the robots: autonomous weapon systems and the Martens Clause. Hofstra Law Review, v. 697, iss. 41, 2014.

FAGOTHEY, A. Right and Reason: ethics in theory and practice. Tan books and publishers, 2000.

FENRICK, W. J. ICRC guidance on direct participation in hostilities. Yearbook of international bumanitarian law, v. 287 , iss. $12,2009$.

FENRICK, W. J. Some international law problems related to prosecution before the International Criminal Tribunal of the Former Yugoslavia. Duke Journal of Comparative and International Law, v. 103, iss. 6, 1995.

FERRARI, G. F. The codification of human rights at national and international level. In: WANG, W. (Ed.) Codification in international perspective: selected papers from the 2nd IACL thematic conference. Springer Science \& Business Media, 2014.

FESCHUK, S. The future and why we should avoid it: killer robots, the apocalypse and other topics of mild concern. Douglas and McIntyre Limited, 2015.

FINN, A.; SCHEDING, S. Developments and challenges for autonomous unmanned vehicles: a compendium. Springer Science \& Business Media, 2010.

FISHER, K. Moral accountability and international criminal law: holding agents of atrocity accountable to the world. Routledge, 2013.

FLECK, D. International humanitarian law after September 11: challenges and the need to respond. In: MCCORMACK, T.; MCDONALD, A. (Ed.). Yearbook of international humanitarian law 2003. Cambridge: Cambridge University Press, 2006.

FLECK, D.; BOTHE, M. The handbook of international humanitarian law. Oxford: Oxford University Press, 2013.

FORSYTHE, D. P. The politics of prisoner abuse: the United States and enemy prisoners after 9/11. Cambridge: Cambridge University Press, 2011.

FRY, J. D. Contextualized legal reviews for the means and methods of warfare: Cave combat and international humanitarian law. Columbia Journal of Transnational Law, v. 453, iss. 44, 2006.

FUNK, T. M. Victims' rights and advocacy at the International Criminal Court. Oxford: Oxford University Press, 2010.

GALLIOTT, J. Military robots: mapping the moral lands- cape. Ashgate Publishing, 2015.

GARCIA, D. Future arms: what international law? (2014) 4 Paper Presented to the Cornwell University Law School. Internal law and International Relations Colloquium. Available at: <http://www.lawschool.cornell. edu/cornell-IL-IR/upload/New-Technologies-Intl-Law-Denise-Garcia-4.pdf $>$.

GARDAM, J. G. Non-combatant immunity as a norm of international humanitarian law. Martinus Nijhoff Publishers, 1993.

GARDAM, J. Proportionality and force in international law. American Journal of International Law, v. 391, iss. 87, 1993.

GARRY, P. Conservatism redefined: a creed for the poor and disadvantaged. Encounter Books, 2013.

GEER, J. G. Public opinion and polling around the world: a historical encyclopaedia. ABC-CLIO, 2004.

GEHRING, R. Loss of civilian protections under the Fourth Geneva Convention and Protocol I XIX-1-2. Military Law and Law of War Review, v. 19, 1980.

GEISS, R.; SIEGRIST, M. Has the armed conflict in Afghanistan affected the rules on the conduct of hostilities? International Review of the Red Cross, v. 93, p. 11-46, 2011.

GENEVA ACADEMY OF INTERNATIONAL HUMANITARIAN LAW. Autonomous weapon systems under international law. Academy Briefing Number, v. 24, iss. 8, 2014.

GERSTING, J. L.; GEMIGNANI, M. C. The computer: history, workings, uses \& limitations. Ardsley House, 1988.

GERTLER, J. US unmanned aerial systems, congressional research service. CreateSpace Independent Publishing Platform, 2012.

GEWIRTH, A. Human dignity as a basis of rights. In: MEYER, M. J.; PARENT, W. A. (Ed.). The constitution of rights: human dignity and American values. Cornell University Press, 1992.

GOODMAN, R. The power to kill or capture enemy combatants. European Journal of International Law, v. 24, 2013.

GOODMAN, R.; JINKS, D. The ICRC interpretive guidance on the notion of direct participation in hosti- 
lities under international humanitarian law: an introduction to the fórum. NYU Journal of International Law and Policy, v. 640, iss. 42, 2010.

GORDON, S. Civilian protection: what's left of the norm. In: PERRIGO, S.; WHITMAN, J. (Ed.). The Geneva conventions under assault. Pluto Press, 2010.

GORMLEY, W. P. The right to life and the rule of non-derogability: peremptory norms of jus cogens. The right to life in international law, v. 128, 1985.

GREENWOOD, C. Battlefield laser weapons in the context of the law on conventional weapons. Blinding weapons, reports of the meetings of experts convened by the International Committee of the Red Cross on battlefield laser weapons 1989-1991, v. 71, 1993.

GREENWOOD, C. Historical development and legal basis. In: FLECK, D. (Ed.) Handbook of international humanitarian law in armed conflict. Oxford: Oxford University Press, 1999.

GROEBEN, C. The conflict in Colombia and the relationship between humanitarian law and human rights law in practice: analysis of the new operational law of the Colombian armed forces. Journal of Conflict and Security Law, v. 141, iss. 16, 2011.

GROSSMAN, D. On killing: the psychological cost of learning to kill in war and society. Open Road Media, 2009.

GROVER, S. C. Schoolchildren as propaganda tools in the war on terror: violating the rights of Afghani children under international law. Springer Science \& Business Media, 2011.

GROVER, S. C. The torture of children during armed conflicts: the icc's failure to prosecute and the negation of children's human dignity. Springer Science \& Business Media, 2013.

GUARINI, M.; BELLO, P. Robotic warfare: Some challenges in moving from non-civilian to civilian theatres. In: LIN, P. et. al. (Ed.). Robot ethics: the ethical and social implications of robotics: MIT Press, 2012.

GULEC v Turkey, ECHR, (1968), Application Number 21593/93, 27 July 1998.

HAGEDORN, A. The invisible soldiers: how America outsourced our security. Simon and Schuster, 2014.

HAMMOND, G. T. The mind of war: John Boyd and american security. Smithsonian Institution Press, 2001.
HAMPSON, F. The principle of proportionality in the law of armed conflict. In: PERRIGO, S.; WHITMAN, J. (Ed.). The Geneva conventions under assault. Pluto Press, 2010.

HANSEN, M. A. Preventing the emasculation of warfare: halting the expansion of human rights law into armed conflict. Military Law Review, v. 19, 2007.

HAREES, L. The mirage of dignity on the highways of buman 'progress': the bystanders' perspective. AuthorHouse, 2012.

HARVEY, C. et. al. Contemporary challenges to the laws of war: essays in honour of Professor Peter Rowe. Cambridge University Press, 2014.

HASSING, R. F. Final causality in nature and human affairs. CUA Press, 1997.

HAUG, H. et. al. Humanity for all: the international red cross and red crescent movement. P. Haupt, 1993.

HELLER, K. One hell of a killing machine: signature strikes and international law. Journal of International Criminal Justice, v. 11, 2013.

HENCKAERTS, J. et. al. Customary international bumanitarian law. Cambridge: Cambridge University Press, 2005.

HENDERSON, I. The contemporary law of targeting. Martinus Nijhoff Publishers, 2009.

HENSEL, H. M. The law of armed conflict. constraints on the contemporary use of military force. Ashgate $\mathrm{Pu}-$ blishing, 2007.

HENSEL, H. M. The legitimate use of military force: the just war tradition and the customary law of armed conflict. Ashgate Publishing, 2013.

HERBACH, J. Into the caves of steel: precaution, cognition and robotic weapons systems under the international law of armed conflict. Amsterdam Law Forum, v. 14, iss. 4, 2012.

HEYNS, C. Autonomous Weapon Systems and buman rights law. Convention on Certain Conventional Weapons, Geneva, Switzerland, 2014. Available at: <http://www. icla.up.ac.za/images/un/speeches/heyns $\% 20 \mathrm{ccw} \% 20$ presentation $\% 20$ aws $\% 20$ and $\% 20$ human $\% 20$ rights. pdf $>$.

HEYNS, C.; KNUCKEY, S. The long term international law implications of targeted killing practices. Har- 
vard International Law Journal, v. 54, 2013.

HIMMA, K. E. Artificial agency, consciousness, and the criteria for moral agency: what properties must an artificial agent have to be a moral agent? 7 th International Computer Ethics Conference, 2007.

HOOGH, A. Articles 4 and 8 of the 2001 ILC Articles on State responsibility, the Tadić case and attribution of acts of Bosnian Serb Authorities to the Federal Republic of Yugoslavia. British Year Book of International Law, v. 255 , n. $76,2001$.

HOWARD, R. E. Dignity, community and human rights. In: AHMED, A. (Ed.). Human rights in cross-cultural perspectives: a quest for consensus. Pennsylvania: University of Pennsylvania Press, 1992.

HUMAN Rights Committee. General Comment 21.

HUMAN Rights Watch Losing Humanity: The case against killer robots. 2012. Available at: <http://www. hrw.org/reports/2012/11/19/losing-humanity-0>.

HUMAN Rights Watch Shaking the foundations: the human rights implications of killer robots. 2014. Available at: <http://www.hrw.org/reports/2014/05/12/ shaking-foundations $>$.

HUMAN Rights Watch, statement to the Convention on Conventional Weapons Informal Meeting of Experts on Lethal Autonomous Weapon Systems May 13, 2014. Available at: <http://www.unog.ch/80256EDD0 06B8954/\%28httpAssets\%29/6CF465B62841F177C1 257CE8004F9E6B/\$file/NGOHRW_LAWS_GenStatement_2014.pdf $>$.

HUSBAND of Maria Fanny Suarez de Guerrero v Columbia Communication Number R 11/45.

ICRAC closing statement to the UN CCW Expert Meeting. 2014. Available at: <http://icrac.net/2014/05/ icrac-closing-statement-to-the-un-ccw-expert-meeting/ $>$.

ICRC intervention during the CCW Meeting. 2014. Available at: <http://www.unog.ch/80256EDD006B 8954/\%28httpAssets\%29/3A14BC199AF51935C125 7CDA0071994D/\$file/ICRC+LAWS+2014+technical + aspects.pdf $>$

ICRC statement to concluding session CCW expert meeting on lethal autonomous weapon systems. 2014. Available at: <http://www.unog.ch/80256EDD006 B8954/\%28httpAssets\%29/8E6FED84C1D0308C
C1257D1500522314/\$file/ICRC_LAWS_FinalStatement_2014.pdf>.

ICRC. A guide to the legal review of new weapons, means and methods of warfare: measures to implement article 36 of additional protocol I of 1977. International Review of the Red Cross, v. 88, n. 864, 2006.

ICRC. Humanitarian debate: law, policy and action: new technologies and warfare. International Review of the Red Cross, v. 886, n.94, 2012.

ILAŞCU and Others v Moldova and Russia. Application No 48787/99 (2004)ECHR Reports 2004-VII, 179.

INSPECTOR-GENERAL of Police $\mathrm{v}$ All Nigeria Peoples Party and Others (2007) AHRLR 179 (NgCA 2007).

INTER-AMERICAN COMMISSION ON HUMAN RIGHTS. Report on terrorism and human Rights. 2002. Available at: <http://www.cidh.oas.org/Terrorism/ Eng/part.c.htm>.

INTERNATIONAL LABOUR OFFICE. Wounded childhood: the use of children in armed conflict in Central Africa. 2003. Available at: < http://www.ilo. org/wcmsp5/groups/public/---ed_emp/---emp_ent/--ifp_crisis/documents/publication/wcms_116566. pdf $>$.

INTERNATIONAL legal protection of human rights in armed conflict. United Nations Publications. 2011. Available at: <http://www.ohchr.org/Documents/Publications/HR_in_armed_conflict.pdf $>$.

ISSA and Others v Turkey, Application No 31821/96. Judgment of 16 Nov 2004.

JACKSON, R. The global covenant: human conduct in a world of states. Oxford University Press, 2000.

JACOBSON, M. Modern weaponry and warfare: The application of article 36 of Additional Protocol I by governments. In: HELM, A. M. (Ed.). The law of war in the $21^{\text {st }}$ century: weaponry and the use of force International law studies. Government Printing Office, 2006.

JENKINS, J. A. The American Courts: a procedural approach. Jones \& Bartlett Learning, 2011.

JENKS, C. Law from above: unmanned aerial systems, use of force, and the law of armed conflict. North Dakota Law Review, v. 665, n. 85, 2009.

JENNINGS, R. Y. The Caroline and McLeod cases. 
American Journal of International Law, v. 92, n. 32, 1938.

JOERDEN, J. C. The promise of human dignity and some of its juridical consequences especially for medical criminal law. In: BEERS, B. et. al. (Ed.) Humanity across international law and biolaw. Cambridge: Cambridge University Press, 2014.

JOHN Khemraadi Baboeram et al $\mathrm{v}$ Suriname UN Official Records of the General Assembly, $40^{\text {th }}$ Session, Supp. Number 40/(A/40/40) Annex X, Communications Number 146 - 154/1983.

JOHNSON, A. M. The morality of autonomous robots. Journal of Military Ethics, v. 134, 2013.

JONES, H. Violence against prisoners of war in the First World War: Britain, France and Germany, 1914-1920. Cambridge: Cambridge University Press, 2011.

JONES, J. Common constitutional traditions: Can the meaning of human dignity under German law guide the European Court of Justice? Public Law, v. 167, 2004.

JONES, T.; LEAMMUKDA, M. G. Requirements-driven autonomous system test design: Building trust relationships. 2011. Available at: <http://www.itea-wsmr. org/ITEA\%20Papers \%20Presentations/2010\%20 ITEA $\% 20$ Papers $\% 20$ and $\% 20$ Presentations $/$ itea_ lvcc_2010_uast_track2_draper_jones_leammukda_paper.pdf>.

KALDOR, M. H.; BEEBE, S. The ultimate weapon is no weapon: human security and the new rules of war and Peace. PublicAffairs, 2010.

KALSHOVEN, F.; ZEGVELD, L. Constraints on the waging of war: an introduction to international humanitarian law. Cambridge: Cambridge University Press, 2011.

KANFRANANN, P. et. al. Humiliation, degradation, debumanisation: Human dignity violated. Springer Science \& Business Media, 2011.

KAPITAN, T. Philosophical perspectives on the Israeli-Palestinian conflict. M.E. Sharpe, 1997.

KASTAN, B. Autonomous Weapon Systems: a coming legal singularity? University of Illinois Journal of Law, Technology and Policy, v. 8, 2013.

KHAN, P. W. The paradox of riskless warfare. Faculty Scholarship Series, v. 4, n. 326, 2002. Available at: <http:// digitalcommons.law.yale.edu/fss_papers/326>.

KINSELLA, H. The image before the weapon: a critical his- tory of the distinction between combatant and civilian. Cornell: Cornell University Press, 2011.

KLIP, A.; SLUITE, G. Annotated leading cases of international criminal tribunals: the international criminal tribunal for the former Yugoslavia. Intersentia, 2001.

KOLB, R.; GAGGIOLI, G. Research handbook on human rights and humanitarian law. Edward Elgar Publishing, 2013.

KOLB, R.; HYDE, R. An introduction to the international law of armed conflicts. Bloomsbury Publishing, 2008.

KRAYNAK, R. P.; TINDER, G. E. In defense of human dignity: essays for our times. Paris: University of Notre Dame Press, 2003.

KRETZMER, D.; KLEIN, E. The concept of buman dignity in human rights discourse. Kluwer Law International, 2002.

KRISHNAN, A. Killer robots: legality and ethicality of autonomous weapons. Ashgate Publishing, 2013.

KROEZE, I. Doing things with value: the case of Ubuntu. Stellenbosch Law Review, v. 252, n. 13, 2002.

KUCURADI, I. Human rights: concepts and problems. LIT Verlag Münster, 2013.

LAMP, N. Conceptions of war and paradigms of compliance: the new war challenge to international humanitarian law. Journal of Conflict and Security law, v. 225, n. 16, 2011.

LARSEN, K. M. Attribution of conduct in peace operations: the ultimate authority and control test. European Journal of International Law, v. 522, n. 19, 2008.

LAWAND, K. Reviewing the Legality of new weapons, means and methods of warfare. International Review of the Red Cross, v. 88, n. 846, 2006.

LEE, M. Universal human dignity: some reflections in the Asian contexto. Asian Journal of Comparative Law, v. 1932, n.3, 2008.

LEGALITY of the threat or use of nuclear weapons, Advisory Opinion (1996) ICJ 226.

LEPSIUS, O. Human dignity and the downing of aircraft: the German Federal Constitutional Court strikes down a prominent anti-terrorism provision in the new Air-transport Security Act. German Law Journal, v. 761, 2006.

LEWIS, J. The case for regulating fully autonomous weapons. Yale Law Journal, v. 1311, 2015. 
Lickiss, $\mathrm{N}$ 'Human dignity and human being' in Malpas, J \& Lickiss, N (eds) (2007) Perspectives on human dignity: A conversation: Springer Science \& Business Media.

LIETZAU, W. K. Combating terrorism: the consequences of moving from law enforcement to war. In: WIPPMAN, D.; EVANGELISTA, M. (Ed.). New wars, new laws? applying the laws of war in the $21^{\text {st }}$ century conflicts. Transnational Publishers, 2005.

LIN P. et. al. Robot ethics: the ethical and social implications of robotics. MIT Press, 2011.

LIN, P. Could buman enhancement turn soldiers into weapons that violate international law? 2013. Available at: <http:// www.theatlantic.com/technology/archive/2013/01/ could-human-enhancement-turn-soldiers-into-weapons-that-violate-international-law-yes/266732/>.

LIN, P. et. al. Robots in war: issues of risk and ethics. In: CAPURRO, R.; NAGENBORG, M. (Ed.). Ethics and Robotics. AKA, 2009.

LIN, P. Introduction to robot ethics. In: LIN, P. et. al. (Ed.). Robot ethics: the ethical and social implications of robotics. MIT Press, 2012.

LIU, H. Categorization and legality of autonomous and remote weapons systems. International Review of the Red Cross, v. 629, n. 94, 2012.

LOIZIDOU v Turkey (Merits). Application No 15318/89 (1996) ECHR Rep 1996-IV, 2216

LORD, C. G. et al. Biased assimilation and attitude polarization: the effects of prior theories on subsequently considered evidence. The Journal of Personality and Social Psychology, 1979.

LUBELL, N. Extraterritorial use of force against non-state actors. Oxford: Oxford University Press, 2010.

MACCORMICK, N. Legal right and social democracy: essays in legal and political philosophy. Clarendon Press, 1982.

MACLEOD, C. Towards a philosophical account of crimes against humanity. European Journal of International Law, p. 281-302, 2010.

MALAWI African Association et al v Mauritania, Communications (2000) AHRLR 149 (ACHPR 2000).

MALPAS, J.; LICKISS, N. Perspectives on human dignity: a conversation. Springer Science \& Business Media, 2007.

MANGLAPUS, R. S. Human rights are not a western
Discovery. World View, v. 4, n. 21, 1978.

MAOGOTO, J. N.; MACCARRICK, G. Typology of conflict: terrorism and the ambiguation of the 1 of war. Gujarat National Law University Law Review, v. 303, n. 31, 2010.

MARAUHN, T. An analysis of the potential impact of lethal autonomous weapon systems on responsibility and accountability for violations of international law. Geneva, 2014. Available at: <http://www.unog.ch/80256EDD006B8954 /\%28httpAssets\%29/35FEA015C2466A57C1257CE 4004BCA51/\$file/Marauhn_MX_Laws_SpeakingNotes_2014.pdf $>$.

MARCHANT, G. et al. International governance of autonomous military robots. Columbia Science and Technology Law Review, v. 280, n. 12, 2011.

MARCHU, I. The fundamental concept of crime in international criminal law: a comparative law analysis. Springer Science \& Business Media, 2013.

MARESCA, L.; MASLEN, S. The banning of anti-personnel landmines: the legal contribution of the International Committee of the Red Cross 1955-1999: Cambridge: Cambridge University Press, 2000.

MARRA, W. C. Understanding 'the loop': regulating the next generation of war machines. Harvard Journal of Law and Public Policy, v. 1155, 36, 2013.

MATHESON, M. J. The United States position on the relation of customary international law to the 1977 protocols additional to the 1949 Geneva Conventions. Amsterdam University Journal of International Law and Policy, v. 420, n. 2, 1987.

MATTHEE, M. et. al. Armed conflict and international law: in search of the human face: liber amicorum in memory of Avril McDonald. Springer Science \& Business Media, 2013.

MAY, L. Crimes against humanity: a normative account. Cambridge: Cambridge University Press, 2005.

MAYER, J. The predator war: what are the risks of the CLA's covert drone program? 2009. Available at : <http://faisalkutty.com/ editors-picks/the-predator-war-what-are-the-risks-of-the-c-i-a-s-covert-drone-program/>.

MAZZESCHI, P. R. Reparation claims by individuals for state breaches of humanitarian law and human rights: an overview. Journal of International Criminal Justice, v. 344, n. 1, 2003. 
MCCANN $\mathrm{v}$ the United Kingdom, 21 ECHR Ser B 148-150.

MCCLELLAND, J. The review of new weapons in accordance with Article 36 of Additional Protocol I. ICRC, v. 397, n. 850, 2003.

MCCORMACK, T. et al. Yearbook of international humanitarian law. Cambridge: Cambridge University Press, 2003.

MCCORMACK, T.; MCDONALD. A yearbook of international bumanitarian law. Cambridge: Cambridge University Press, 2006.

MCCRUDDEN, C. Human dignity and judicial interpretation of human rights. European Journal of International Law, v. 655, n. 19, 2008.

MCDONALD, A. Hors de combat: post-September 11 challenges to the rules. In: HENSEL, H. M. (Ed.). The legitimate use of military force: the just war tradition and the customary law of armed conflict. Ashgate Publishing, 2008.

MCDOUGAL, M. S.; FELICIANO, F. P. Law and minimum world public order. New Haven: Yale University Press, 1961.

MCKENZIE v Jamaica, Case 12.023, Inter-American Commission on Human Rights, Report Number 41/00, OEA/Ser.L/V/II.106 doc.3 (2000).

MCLNTOSH, S. The wingman-philosopher of MiG alley: John Boyd and the OODA loop. Air Power History, v. 26, n. $58,2011$.

MELDEN, A. Dignity, worth, and rights. In: MEYER, M. J. et. al. The constitution of rights: human dignity and American values. Cornell University Press, 1992.

MELZER, N. Human rights implications of the usage of drones and unmanned robots in warfare. European Parliament Directorate-General for External Policies, v. 39, 2013.

MELZER, N. ICRC's interpretive guidance on the notion of direct participation in hostilities under international humanitarian Law. International Committee of the Red Cross, v. 1.

MELZER, N. Keeping the balance between military necessity and humanity: a response to four critiques on the ICRC's Interpretive guidance on the notion of direct participation in hostilities. NYU Journal of International Law and Policy, v. 831, 42, 2010.
MELZER, N. Targeted killing in international law. Oxford: Oxford University Press, 2008.

MENDES, E. P. Global governance and international law: combating the tragic flaw. Routledge, 2014.

MERON, T. Law crimes law comes of age. Clarendon Press, 1998.

MERON, T. The Martins Clause, principles of humanity, and dictates of public conscience. American Journal of International Law, v. 79, n. 94, 2000.

METTRAUX, G. The law of command responsibility. Oxford: Oxford University Press, 2009.

MEYER, M.; PARENT, W. The constitution of rights: human dignity and American values London. Cornell University Press, 1992.

MICHALOWSKI, S. Corporate accountability in the context of transitional justice. Routledge, 2014.

MIHR, A.; GIBNEY, M. The SAGE handbook of buman rights. SAGE, 2014.

MILANOVIC, M. Extraterritorial application of human rights treaties: law, principles, and policy. Oxford: Oxford University Press, 2011.

MILANOVIC, M. Norm conflicts, international humanitarian law, and human rights law. In: MILANOVIC, $\mathrm{M}$ (Ed.). Extraterritorial application of human rights treaties: law, principles, and policy. Oxford: Oxford University Press, 2011.

MILANOVIC, M. State Responsibility for Genocide. European Journal of International Law, v. 577, n. 17, 2006.

MILITARY and Paramilitary Activities in and against Nicaragua, Nicaragua $v$ the United States of America ICJ Reports 1986

MILITARY Junta case, Judgement, Argentina, National Court of Appeals.

MKOGORO, Y. Ubuntu and the law in South Africa. Buffalo Human Rights Law Review, v. 15, n. 4, 1998.

MOMČILO Mandic, Case No. X-KR-05/58, $2^{\text {nd }}$ instance Verdict, 18 July 2007.

MOORE, N. M. The political roots of racial tracking in American criminal justice. Cambridge: Cambridge University Press, 2015.

MORLEY, J. Autonomous Weapons Stir Geneva Debate. 2014. Available at: <https://www.armscontrol. 
org/act/2014_06/news/Autonomous-Weapons-Stir-Geneva-Debate>.

MORRIS, B. The dignity of man. Ethics, v. 57, 1946.

MOSIER, K. L.; SKITKA, L. J. Human decision makers and automated decision aids: Made for each other? In: MOULOUA, M (Ed.). Automation and human performance: theory and applications. Taylor \& Francis, 1996.

MUGWANYA, G. W. The contribution of the International Criminal Tribunal of Rwanda to the development of international criminal law. In: MURUNGU, C.; BIEGON, J. (Ed.). Prosecuting international crimes in Africa. PULP, 2011.

MURUNGU, C. Prosecution and punishment of international crimes by the Special Court for Sierra Leone. In: MURUNGU, C.; BIEGON, J. (Ed.). Prosecuting international crimes in Africa. PULP, 2011.

NACHOVA v Bulgaria ECHR( 16 June 2005) Ser A 42

NASU, H.; MCLAUGHLIN, R. New technologies and the law of armed conflict. Springer Science \& Business Media, 2013.

NEIRA Allegria et al v Peru, IACHR, Series C, No. 20 (1995), 19 January 1995.

NICKS, D. US takes steps toward signing Landmine Ban Treaty. 2014. Available at: <http://time.com/2933269/ us-landmine-treaty-ottawa/ $>$.

NONAMI, K. et. al. Autonomous control systems and vehicles: intelligent unmanned systems. Springer Science \& Business Media, 2013.

NOVAK, R. The global decline of the mandatory death penalty: constitutional jurisprudence and legislative reform in Africa, Asia, and the Caribbean. Ashgate Publishing, 2014.

O'CONNELL, M. E. Unlawful killing with combat drones a case study of Pakistan, 2004-2009. Notre Dame Law School Legal Studies, v. 2, 2010.

O'GORMANN, R.; ABBOT'T, C, Remote control war: unmanned combat air vehicles in China, India, Israel, Iran, Russia and Turkey. Open Briefing, v. 2, 2013. Available at: <http://issuu.com/openbriefing/docs/remote_control_war $>$.

OBERLEITNER, G. Human rights in armed conflict. Cambridge: Cambridge University Press, 2015.

OBURA, K. Duty to prosecute international crimes un- der international law. In: MURUNGU, C.; BIEGON, J. (Ed.). Prosecuting international crimes in Africa. PULP, 2011.

OKIMOTO, K. The distinction and relationship between jus ad bellum and jus in bello. Hart, 2011.

ORAKHELASHVILI, A. Research handbook on the theory and history of international law. Edward Elgar Publishing, 2011.

ORENTLICHER, D. F. The law of universal conscience: genocide and crime against humanity. Available at: <http://www1.ushmm.org/conscience/analysis/details/1998-12-09/orentlicher.pdf $>$.

ORFORD. A international law and its others. Cambridge: Cambridge University Press, 2006.

OSINGA, F. P. B. Science, strategy and war: the strategic theory of John Boyd. Routledge, 2006.

OT'TO, R. Targeted killings and international law: with special regard to human rights and international humanitarian law. Springer Science \& Business Media, 2011.

OWENS, E. Religion and the death penalty: a call for reckoning. Wm. B. Eerdmans Publishing, 2004.

PAGE, L. US war robots in Iraq 'turned guns' on fleshy comrades: kill-droid rebellion thwarted this time. 2008. Available at <http://www.theregister.co.uk/2008/04/11/ us_war_robot_rebellion_iraq/ $>$.

PARASURAMAN, R. et al. A model for types and levels of human interaction with automation. IEEE Transactions on systems, man, and cybernetics, v. 30, p. 286-288, 2000.

PARASURAMAN, R. et al. A model for types and levels of human interaction with automation. IEEE Transactions on systems, man, and cybernetics, v. 30, p. 286-8, 2000. Available at: <http://ieeexplore.ieee.org/>.

PARKS, H. W. Conventional weapons and weapons reviews. Year Book of International Humanitarian Law, v. 55, n. 8,2005 .

PARKS, H. W. Joint service shotgun program. Army Law, v. 16, 1997.

PATTISON, J. Humanitarian intervention and the responsibility to protect: who should intervene? Oxford: Oxford University Press, 2010.

PAUMGARTEN, N. 'Here'slooking atyou: should we worry about the rise of drone? 2012. Available at: <http:/ / www. newyorker.com/reporting/2012/05/14/120514fa_ fact_paumgarten $>$. 
PERRIGO, S.; WHITMAN, J. The Geneva conventions under assault. Pluto Press, 2010.

PERRIN, P. War and public health: extending the concept of public health for the victims of armed conflict. 1998. Available at: <http://www.who.int/hac/about/6676. $\mathrm{pdf}>$.

PICTET, J. S. Humanity. International Review of the Red Cross, v. 158, 1995.

PIETH, M.; IVORY, R. Corporate criminal liability: emergence, convergence and risk: Springer Science \& Business Media, 2011.

PINKER, S. The blank slate: the modern denial of human nature. Penguin UK, 2002.

PLATT, P. W. Human dignity and the conflict of rights. Idealistic Studies, v. 174, n. 2, 1972.

PLAW, A. Targeting terrorists: a license to kill? Ashgate Publishing, 2013.

PRIMORATZ, I.; Lovell, D. W. Protecting civilians during violent conflict: theoretical and practical issues for the $21 \mathrm{st}$ century. Ashgate Publishing, 2013.

PROSECUTOR v Aleksovski, Case No IT-95-14/1-T, Judgement, 25 June 1999.

PROSECUTOR v Delalic and Others, Case No 9621-T, Judgement, 16 Nov 1998, para 543; Prosecutor $v$ Blaskic, Case No IT-95-14-T, Judgement, 3 Mar 2000, pars 154-155.

PROSECUTOR v Jean-Pierre Bemba, Case No. ICC01/05-01/08, Confirmation of Charges Decision, Pre-Trial Chambers, 12 January 200.

PROSECUTOR v Kordić and Čerkez. Case No IT-95$-14 / 2-\mathrm{T}$.

PROSECUTOR v Milorac Krnojelac. Case No. IT-9725-A, Trial Judgement.

PROSECUTOR v Naletilic and Martinovic. Case No IT-98-34-T.

PROSECUTOR v Naser Oric. Case No. IT-03-68-A, Appeal Judgement, 3 July 2008.

PROSECUTOR v Raševic et al. Verdict at First Instance.

PROSECUTOR v Stanislav Galic. Case No. IT-9829-T, Trial Judgement, 5 Dec. 2003.

PROSECUTOR v Stupar Milos et al. No.
X-KRŽZ-05/24-3, Verdict at Second Instance, 2010.

PROSECUTOR v Tadić. Case No IT-94-1-A (1999) 38 ILM 1518.

PROSECUTOR v Tadic. Case No IT-94-1-I Decision on Defence Motion for Interlocutory Appeal on Jurisdiction, (ICTY) (2 October 1995).

PROSECUTOR v Zejnil Delalic Čelebici. Case No. IT96-21-T, Trial Judgement, 16 November 1998.

PUNCH, M. Shoot to kill: police accountability, firearms and fatal force. Policy Press, 2010.

QUENIVET, N.; DAVIS, S. S. International law and armed conflict: challenges in the 21 st century. T.M.C. Asser Press, 2010.

RAMCHARAN, B. G. The right to life in international law. Martinus Nijhoff Publishers, 1985.

RAPPERT, B. Non-lethal weapons as legitimising forces? technology, politics and the management of conflict. Routledge, 2004.

RATNER, R. T. et. al. Accountability for human rights atrocities in international law: beyond the nuremburg legacy. Oxford: Oxford University Press, 2009.

RAYFUSE, R. War and the environment. new approaches to protecting the environment in relation to armed conflict. Martinus Nijhoff Publishers, 2014.

RAZ, J. The morality of freedom. Clarendon Press, 1986.

REISMAN, W. The quest for world order and human dignity in the twenty-first century: constitutive process and individual commitment. Martinus Nijhoff Publishers, 2013.

REISMAN, W. M.; STEVICK, D. The applicability of international law standards to United Nations Economic Sanctions Programmes. European Journal of International Law, v. 9, p. 94-95, 1998.

REISMAN, W.; SILK, J. Which law applies to the Afghan conflict? American Journal of International Law, v. 465, n. 82, 1998.

REPORT of the Secretary-General on the role of science and technology in the context of international security and disarmament A/53/202.

REPORT of the Special Rapporteur on extrajudicial, summary or arbitrary executions, Christof Heyns, 12 August 2013.

REPORT of the UN Secretary General, Boutros Bou- 
tros-Ghali, UN Doc. S/25704 (1993) para 48.

RIZA, M. S. Killing without heart. limits on robotic warfare in an age of persistent conflict. Potomac Books, 2013.

ROBERTSON, H. B. The principle of the military objective in the law of armed conflict. United States Air Force Academy Journal of Legal Studies, v. 8, p. 35-70, 1997.

ROFF, H. M. killing in war: responsibility, liability and lethal autonomous robots. In: HENSCHKE, A. et. al. Handbook of ethics and war: just war theory in the $21 \mathrm{st}$ century. Routledge, 2013.

ROFF, H. M. killing in war: responsibility, liability and lethal autonomous robots. 2014. Available at: <https:/ / www.academia.edu/2606840/Killing_in_War_Responsibility_Liability_and_Lethal_Autonomous_Robots $>$.

ROGERS, P. Unmanned Air Systems: the future of air \& sea power? Institut Français des Relations Internationales (IFRI) Focus Stratégique, v. 49, 2014.

ROSS, S. The drone is the most feared and hated weapon in history. 2013. Available at: <http://beforeitsnews.com/ eu/2013/05/the-drone-is-the-most-feared-and-hated-weapon-in-history-2520054.html>.

ROTHBART, D. et. al. Civilians and modern war: armed conflict and the ideology of violence. Routledge, 2012.

RUBENFELD, S.; BENEDICT, S. Human subjects research after the Holocaust. Springer, 2014.

RUIZ, J.; HUMMER, D. Handbook of police administration. CRC Press, 2007.

SANDOZ, Y. et al. Commentary on the Additional Protocols of 8 June 1977 to the Geneva Conventions of 12 August 1949. ICRC, Geneva, 1987.

SASSÒLI, M. Autonomous weapons and international humanitarian law: Advantages, open technical questions and legal issues to be clarified. International Law Studies Naval War College, v. 324, n. 90, 2014.

SASSOLI, M. Humanitarian law and international criminal law. In: CASSESE, A. (Ed.). The Oxford companion to international criminal justice. Oxford: Oxford University Press, 2009.

SAXON, D. International humanitarian law and the changing technology of war. Martinus Nijhoff Publishers, 2013.

SCHABAS, W. Hate speech in Rwanda: The road to genocide. McGill Law Journal, v. 144, 2000.
SCHARRE, P. Autonomy, "killer robots and human control in the use of force: part II, 2014. Available at: <http:// justsecurity.org/12712/autonomy-killer-robots-human-control-force-part-ii/ $>$.

SCHMIT'T, C. The concept of the political. Chicago: University of Chicago Press, 2007.

SCHMITT, M. 'Humanitarian law and direct participation in hostilities by private contractors or civilian employees. Chicago Journal of International Law, v. 511, n 379, 2005.

SCHMIT'T, M. Autonomous weapon systems and international humanitarian law: a reply to the critics. Harvard National Security Journal, v. 33, 2013.

SCHMITT, M. Deconstructing direct participation in hostilities: the constitutive elements. NYU Journal of International Law and Policy, v. 699, n. 42, 2010.

SCHMITT, M. Deconstructing direct participation in hostilities: the constitutive elements. NYU Journal of International Law and Policy, v. 699, n. 42, 2010.

SCHMIT'T, M. Precision attack and international humanitarian law. International Review of the Red Cross, v. 445, n. $87,2005$.

SCHMIT'T, M. Tallinn manual on the international law applicable to cyber warfare. 2013.

SCHMITT, M. The interpretive guidance on the notion of direct participation in hostilities: a critical analysis. Harvard National Law and Security Journal, v. 37, n. 1, 2010.

SCHMIT'T, M. The Manual on the Law of Non-International Armed Conflict. International Institute of Humanitarian Law, v. 12, 2006.

SCHMIT'T, M.; THURNHER, J. S. Out of the loop: autonomous weapon systems and the law of armed conflict. Harvard National Security Journal, v. 258, 2013.

SCHWARZENBERGER, G. The legality of nuclear weapons. Stevens, 1958.

SEIBERT-FOHR, A. Prosecuting serious human rights violations. Oxford: Oxford University Press, 2009.

SHACHTMAN, N. Robot cannon kills 9, wounds 14. 2007. Available at: <http://www.wired.com/dangerroom/2007/10/robot-cannon-ki/>.

SHAH, N. A. Islamic law and the law of armed conflict. the conflict in Pakistan. Taylor \& Francis, 2011.

SHAH, S. A. International law and drone strikes in Pakistan: 
the legal and socio-political aspects: Routledge, 2014.

SHARKEY, N. Automated killers and the computing profession. Computer, v. 122, 40, 2007.

SHARKEY, N. E.; SUCHMAN, L. Wishful mnemonics and autonomous killing machines. Proceedings of the AISB, v. 136, p. 14-22, 2013.

SHARKEY, N. Grounds for discrimination: autonomous robot weapons. RUSI Defence Systems, p. 88-89, 2008. Available at: <http://rusi.org/downloads/ assets/23sharkey.pdf $>$.

SHARKEY, N. Killing made easy: From joysticks to politics. In: LIN, P. et. al. (Ed.). Robot ethics: the ethical and social implications of robotics: MIT Press, 2012.

SHARKEY, N. Presentation at the 2014 CCW Expert Meeting on Lethal Autonomous Weapon Systems audio. Available at: <http://www.unog.ch/80256EDD006B8954/\%28h ttpAssets\%29/D11C3EF955B32937C1257CED00462 04D/\$file/1063.MP3>.

SHARKEY, N. The evitability of autonomous robot warfare. International Review of the Red Cross, 2012.

SHARKEY, N. Towards a principle for the human supervisory control of robot weapons. Politica \& Società, v. 2, 2014.

SHELTON, D. Regional protection of human rights. OUP USA, 2013.

SHOHAM, S. G. International handbook of penology and criminal justice. CRC Press, 2007.

SHOLES, E. Evolution of a UAV autonomy classification taxonomy' Remarks at the IEEE Aerospace Conference Digest. Aviation and Missile Research, Development and Engineering Centre.

SIEGEL, L.; WORRALL, J. Essentials of criminal justice. Cengage Learning, 2014.

SIMONS, P.; MACKLIN, A. The governance gap: extractive industries, buman rights, and the home state advantage. Routledge, 2014.

SINGER, P. W. In the loop? armed robots and the future of war, 2009. Available at: <http://www.brookings. $\mathrm{edu} /$ research/articles/2009/01/28-robots-singer>.

SINGER, P. W. The predator comes home: a primer on domestic drones, their huge business opportunities, and their deep political, moral, and legal challenges, 2013. Available at: <http://www.brookings.edu/research/ papers/2013/03/08-drones-singer>.

SINGER, P. W. Wired for war: the robotics revolution and conflict in the 21st century. Penguin, 2009.

SIVAKUMARAN, S. The Law of non-international armed conflict. Oxford: Oxford University Press, 2012.

SKLEROV, M. J. Solving the dilemma of state responses to cyber-attacks: a justification for the use of active defenses against states who neglect their duty to prevent. Michigan International Law Review, v. 14, n. 201, 2010.

SLIM, J. Sharing a universal ethic: The principle of humanity in war. International Journal of Human Rights, v. 28, 1998.

SMIDT, M. Yamahita, Medina, and beyond: Command responsibility in contemporary military operations. $\mathrm{Mi}$ litary Law Review, v. 176, n. 164, 2000.

SOLIS, G. D. The law of armed conflict: international bumanitarian law in war. Cambridge: Cambridge University Press, 2010.

SPARROW, R. Killer robots. Journal of Applied Philosophy, v. 73, n. 24, 2007.

SPARROW, R. Robotic weapons and the future of war. In: WOLFENDALE, J.; TRIPODI, P. (Ed.). New wars and new soldiers: military ethics in the contemporary world. Ashgate Publishing, 2011.

SPRINGER, P. J. Military robots and drones. ABC-CLIO, 2013.

STARR-DEELEN, D. Presidential policies on terrorism: from Ronald Reagan to Barack Obama. Palgrave Macmillan, 2014.

STATEMENT of the Croatia delegate to the CCW meeting of experts lethal autonomous weapon systems, 2014. Available at: <http://www.reachingcriticalwill.org/images/documents/Disarmament-fora/ ccw/2014/statements/16May_Croatia.pdf>.

STATEMENT of the German delegate to the CCW meeting of experts lethal autonomous weapon systems, 2014. Available at: <http://www.reachingcriticalwill.org/images/documents/Disarmament-fora/ ccw/2014/statements/13May_Germany.pdf>.

STATEMENT of the Norway delegate to the CCW meeting of experts lethal autonomous weapon systems, 2014. Available at: <http://www.reachingcriti- 
calwill.org/images/documents/Disarmament-fora/ ccw/2014/statements/13May_Norway.pdf>.

STATEMENT of the Switzerland delegate to the CCW meeting of experts lethal autonomous weapon systems, 2014. Available at: <http://www.reachingcriticalwill.org/images/documents/Disarmament-fora/ ccw/2014/statements/13May_Switzerland.pdf>.

STEINHARDT, R. G. Weapons and the human rights responsibilities of multinational corporations. In: CASEY-MASLEN, S. (Ed.). Weapons under international buman rights law. Cambridge: Cambridge University Press, 2014.

STRANGE, S. K.; ZUPKO, J. Stoicism: traditions and transformation. Cambridge: Cambridge University Press, 2004.

STRAWSER, J. Killing by remote control: the ethics of an unmanned military. Oxford: Oxford University Press, 2013.

STRAWSER, J. Opposing perspectives on the drone debate. Palgrave Macmillan, 2014.

SWART, B. Modes of international criminal liability. In: CASSESE, A. (Ed.). Oxford companion to international criminal justice. Oxford: Oxford University Press, 2009.

TALMON, S. The various control tests in the law of state responsibility and the responsibility of outside powers for acts of secessionist. International and Comparative Law Quarterly, v. 6, n. 58, 2009.

TAMS, C. J.; SLOAN, J. The development of international law by the International Court of Justice. Oxford: Oxford University Press, 2013.

TAN, A. Responsibility and control in international law and beyond. 2013. Available at: <http://www.thehagueinstituteforglobaljustice.org/index.php?page $=$ News-News ArticlesRecent_NewsResponsibility_and_Control_in_ International_Law_and_Beyond\&pid=138\&id $=108>$.

TAYLOR, G. US intelligence warily watches for threats to US now that 87 nations possess drones. Available at: <http:// www.washingtontimes.com/news/2013/nov/10/skys-the-limit-for-wide-wild-world-of-drones $/$ ?page $=$ all $>$.

TEITEL, R. G. Humanity's law. Oxford: Oxford University Press, 2011.

THÜRER, D. International humanitarian law: theory, practice, contexto. Martinus Nijhoff Publishers, 2011.
THURMAN, Q. C.; $\square$ JAMIESON, J. D. Police problem solving. Routledge, 2014.

THURNHER, J. S. No one at the controls: legal implications of autonomous targeting. Joint Force Q $v .80, \mathrm{n}$. 67, 2012.

TICEHURST, R. The Martens Clause and the laws of armed conflict. International Law Review of the Red Cross, v. 126, n. $317,1997$.

TODD, G. H. Armed attack in cyberspace: deterring asymmetric warfare with an asymmetric definition. Air Force Law Review, v. 65, n. 64, 2009.

TOORN, D. Direct participation in hostilities: a legal and practical road test of the International Committee of the Red Cross's guidance through Afghanistan. Australian international law jornal, v. 21, n. 17, 2010.

TRINDADE, A. The construction of a bumanized international law: a collection of individual opinions 1991-2013. Hotei Publishing, 2014.

U.N Human Rights Committee Comment Number 305/1988 UN Doc CCPR/C/39/D/305/1998, 15 August 1990 .

U.N Human Rights Committee General Comment Number 6 HRI/GEN/1/Rev 61982.

UN A/HRC/14/24/Add. 6 Report of the Special Rapporteur on extrajudicial, summary or arbitrary executions, Philip Alston.

UN Declaration of Basic Principles of Justice for Victims of Crime and Abuse of Power. 'Persons' referred in the definition of victims can be 'the immediate family or dependents of the direct victim or person who have suffered the harm.'

UN General Assembly. Resolution 1653 ХVI.

UN Sub-Commission on Human Rights. Resolution 1989/39.

UNITED NATIONS. Good governance practices for the protection of human rights. United Nations Publications, 2007.

URUENA, R. Deciding what is humane: towards a critical reading of humanity as a normative standard in international law. In: BEERS, B. et. al. (Ed.). Humanity across international law and biolaw. Cambridge: Cambridge University Press, 2014.

VEUTHEY, M. Public conscience in international humanitarian law today. In: HORST, F. et. al. (Ed.). Krisen- 
sicherung und humanitärer schutz: crisis management and humanitarian protection. Berliner Wissenschaftsverlag, 2004.

VOGEL, R. J. Drone warfare and the law of armed conflict. Denver Journal of International Law and Policy, v. 122, n. 39, 2010.

WAGNER, M. Taking humans out of the loop: implications for international humanitarian law. Journal of Law Information and Science, v. 5, n. 21, 2011.

WAGNER, M. The dehumanization of international humanitarian law: legal, ethical, and political implications of autonomous weapon systems. 2012. Available at: < http:/ / robots.law.miami.edu/wpcontent/uploads/2012/01/ Wagner_Dehumanization_of_international_humanitarian_law.pdf $>$.

WALDRON, J. Dignity, rank, and rights. Oxford University Press, 2012.

WALDRON, J. The dignity of groups. Acta Juridica, v. 66, 2008.

WALLACH, W. A dangerous master: how to keep technology from slipping beyond our control. Basic Books, 2015.

WALLACH, W. From robots to techno sapiens: Ethics, law and public policy in the development of robotics and neurotechnologies. Law, Innovation and Technology, v. 194, n. 3, 2011.

WALZER, M. Just and unjust wars. Basic Books, 1977.

WATKIN, K. Controlling the use of force: a role of human rights norms in contemporary armed conflict. The American Journal of International Law, v. 98, p. 2-8, 2004.

WATKIN, K. Humans in the cross-hairs: Targeting and assassination in contemporary armed conflict. In: WIPPMAN, D.; EVANGELISTA, M. (Ed.). New wars, new laws? applying the laws of war in the $21^{\text {st }}$ century conflicts. Transnational Publishers, 2005.

WATKIN, K. Opportunity lost: organized armed groups and the ICRC 'direct participation in hostilities' interpretive guidance. Journal of International Law and Policy, v. 692, n. 42, 2010.

WATSON, S. Riot control drone to shoot pepper spray bullets at protesters. 2014. Available at: <http://www.prisonplanet.com/riot-control-drone-to-shoot-pepper-spray-bullets-at-protesters.html>.
WEINBERG, L. Global terrorismo. The Rosen Publishing Group, 2009.

WEINBERGER, S. Charity battles imaginary killing machines. 2008. Available at: <http://www.wired. com/2008/03/charity-will-ba/>.

WEISSTUB, D. Honour, dignity and the framing of multiculturalists values. In: KRETZMER, D.; KLEIN, E. (Ed.). The concept of human dignity in human rights discourse. Kluwer Law International, 2002.

WEISSTUB, D. N.; PINTOS, G. D. Autonomy and human rights in health care: an international perspective. Springer Science \& Business Media, 2007.

WELLS-GRECO, M. Operation Cast Lead: jus in bello proportionality. Netherlands International Law Review, v. 397, n. 57, 2010.

WEMMERS, J. Victim reparation and the International Criminal Court. International Review of Victimology, v. 123, n. 16, 2009.

WHITING, A. In International criminal prosecutions, justice delayed can be justice delivered. Harvard International Law Journal, v. 323, n. 50, 2009.

WILLIAM, C. et al. Understanding 'the loop': regulating the next generation of war machines. Harvard Journal of Law and Public Policy, v. 1144, n. 36, 2013.

WOLF, R. In defence of anarchism. University of California Press, 1970.

WOOD, B. Head of arms control and security trade. International secretariat, amnesty international, statement to the 2014 CCW Meeting. 2014. Available at: <http:// www.unog.ch/80256EDD006B8954/\%28httpAssets\% 29/1E7C4FC2E94376D6C1257CD7006A8698/\$file/ NGOAmnesty_MX_LAWS_2014.pdf>.

WOOLMAN, S. Constitutional conversations. PULP, 2008.

ZASTROW, C.; KIRST-ASHMAN, K. Understanding buman behaviour and the social environment. Cengage Learning, 2006.

ZEGEVELD, L. 'Victims' reparations claims and International Criminal Courts. Journal of International Criminal Justice, v. 79, n. 8, 2010. 
Para publicar na Revista de Direito Internacional, acesse o endereço eletrônico www.rdi.uniceub.br ou www.brazilianjournal.org.

Observe as normas de publicação, para facilitar e agilizar o trabalho de edição. 